NBER WORKING PAPER SERIES

\title{
THE RELATIONSHIP BETWEEN EDUCATION AND ADULT MORTALITY IN THE UNITED STATES
}

\author{
Adriana Lleras-Muney \\ Working Paper 8986 \\ http://www.nber.org/papers/w8986 \\ NATIONAL BUREAU OF ECONOMIC RESEARCH \\ 1050 Massachusetts Avenue \\ Cambridge, MA 02138 \\ June 2002
}

I would like to thank Ann Bartel, Francisco Ciocchini, Ana Corbacho, Rajeev Dehejia, Phoebus Dhrymes, William Gentry, Bo Honore, Kenneth Leonard, Manuel Lobato, Christina Paxson, Alexander Peterhansl, Nachum Sicherman and the seminar participants at the Federal Reserve Board, Harvard University, Michigan State University, MIT, Princeton University, University of Montreal, UNC-Greensboro, Princeton University, UC Berkeley, UC Davis, UC Irvine, University of Illinois at Urbana Champaign for their comments and suggestions. I am especially grateful to my advisor Sherry Glied who fully supported me throughout this project. All errors are mine. This research was partially funded by Columbia University's Public Policy Consortium, and the Bradley Foundation. The views expressed herein are those of the author and not necessarily those of the National Bureau of Economic Research.

(C) 2002 by Adriana Lleras-Muney. All rights reserved. Short sections of text, not to exceed two paragraphs, may be quoted without explicit permission provided that full credit, including (C) notice, is given to the source. 
The Relationship Between Education and Adult Mortality in the United States Adriana Lleras-Muney

NBER Working Paper No. 8986

June 2002

JEL No. I12, I20, J10, J18, N32, N42

\begin{abstract}
Prior research has uncovered a large and positive correlation between education and health. This paper examines whether education has a causal impact on health. I follow synthetic cohorts using successive U.S. censuses to estimate the impact of educational attainment on mortality rates. I use compulsory education laws from 1915 to 1939 as instruments for education. The results suggest that education has a causal impact on mortality, and that this effect is perhaps larger than has been previously estimated in the literature.
\end{abstract}

\author{
Adriana Lleras-Muney \\ Department of Economics \\ Princeton University \\ Princeton, NJ 08540 \\ and NBER \\ alleras@princeton.edu
}




\section{Introduction}

Access to health care insurance, ${ }^{1}$ expenditures on health care, ${ }^{2}$ and even income levels ${ }^{3}$ have been shown to have little effect on health. On the other hand, there is a large and positive correlation between education and health (Grossman and Kaestner 1997). This correlation is strong and significant even after controlling for different measures of socio-economic status, such as income and race, and regardless of how health is measured (morbidity rates, self-reported health status or other measures of health). Given that the measured effects of education are large, investments in education might prove to be a cost-effective means of achieving better health, ${ }^{4}$ if education indeed helps us to be healthier. But prior research has not ascertained whether the relationship between education and health is causal.

The purpose of this paper is to determine whether education has a causal effect on health, in particular on mortality. The negative relationship between education and mortality, the most basic measure of health, has become well established since the famous Kitagawa and Hauser (1973) study, which found significant differences in mortality rates across educational categories for both sexes. More recent studies (e.g. Christenson and Johnson, 1995, Deaton and Paxson, 1999) confirm these findings. Elo and Preston (1996) control for a variety of other mortality factors such as income, race, marital status, region of residence, and region of birth. Rogers et al. (2000) further control for access to health care, insurance, smoking, exercise, occupation, and other factors. Figures 1 and 2 document this relationship using consecutive census data for the US: in all cohorts, those who survive have higher education than those who do not.

The existing literature has explained this correlation in three ways. One controversial hypothesis is that education increases health, either because education makes people better decision-

\footnotetext{
${ }^{1}$ See Newhouse (1993).

${ }^{2}$ For example see Filmer and Prichett (1997).

${ }^{3}$ Grossman (1975) shows that income does not affect health beyond a certain threshold.

${ }^{4}$ This was first suggested by Auster et al (1969).
} 
makers (Grossman 1975) and/or because more educated people have better information about health (Kenkel 1991, Rosenzweig and Schultz 1981). Another possibility is that poor health results in little education (Perri 1984, Curry and Hyson 1999). Finally, this correlation could be caused by a third unobserved variable that affects both education and health, for example genetic characteristics or parental background. Many studies have attempted to include these factors. ${ }^{5}$ However, Fuchs (1982) argued that discount rates (which no study controls for) would also explain the correlation: people who are impatient invest little in education and health, while people who are patient invest a lot in both. ${ }^{6}$ Of course, these theories are not necessarily mutually exclusive.

In this paper I address this issue using a unique quasi-natural experiment: between 1915 and 1939, at least 30 states changed their compulsory schooling laws and child labor laws. If compulsory schooling laws forced people to get more schooling than they would have chosen otherwise, and if education increases health, then individuals who spent their teens in states that required them to go to school for more years should be relatively healthier and live longer. The intuition that compulsory education laws provide a natural experiment was put forward first by Angrist and Krueger (1991). They argued that because compulsory education laws forced individuals to stay in school until a certain age, those born in later quarters would stay in school longer. Although they were criticized for their choice of quarter of birth as an instrument, ${ }^{7}$ the underlying principle is appealing and implementable. ${ }^{8}$

No other papers have used natural experiments to measure the effect of education on mortality. A few studies (Berger and Leigh 1988, Sander 1995, and Leigh and Dhir 1997) have used instrumental variable (IV) estimation with other measures of health, such as blood pressure, smoking

\footnotetext{
5 Wolfe and Behrman (1987), Duleep (1986) and Menchik (1993) find no education effect once controls are added.

${ }^{6}$ Fuchs (1982) and Farrel and Fuchs (1982) examined this issue but their evidence is inconclusive. Munasinghe and Sicherman (2000) do find that time preference plays an important role in the determination of smoking.

7 See Bound, Jaeger and Baker (1995) and Bound and Jaeger (1996).

8 Harmon and Walker (1995) look at the effects of the laws in the UK. Meghir and Palme (1999) used Swedish data. Acemoglu and Angrist (1999) used US laws to determine the size of the social returns to education.
} 
or exercise. ${ }^{9} \quad$ But these studies are inconclusive because each paper's choice of instrument is questionable. For example, all of these studies use parents' background/education as instruments, but we know these are correlated with children's health, ${ }^{10}$ and furthermore, we know that health shocks during childhood or gestation have persistent health effects into adulthood. ${ }^{11}$ Income and education expenditures in state-of-birth could serve as instruments (Berger and Leigh 1988), but again they might be correlated with state expenditures on health, state industrial composition and other state characteristics that affect health.

Using the 1960, 1970 and 1980 Censuses of the US, I select those individuals who were 14 years of age between 1915 and 1939. I then construct synthetic cohorts and follow them over time to calculate their mortality rates. I then match cohorts to the compulsory attendance and child labor laws that were in place in their state-of-birth when they were 14 years old. The census data have not been used to calculate mortality rates before in economic analyses. ${ }^{12}$ This method could be used to analyze mortality experiences in periods where no other data are available.

Several IV estimations are presented, including an original two-stage procedure for grouped data that can be applied when the first stage can be estimated at the individual level but the second stage can only be estimated at the aggregate level. This procedure, inspired by the traditional two-stage least squares (2SLS) method, can easily be applied to other cases as well.

The results provide evidence that suggests there is a causal effect of education on mortality and that this effect is perhaps larger than the previous literature suggests. While GLS estimates

\footnotetext{
${ }^{9}$ Berger and Leigh (1988) estimate the effect of education on blood pressure using the NHANES I. They use state-of-birth, income and education expenditures per capita from year-of-birth to age 6 in state-of-birth, and dummies for ancestry as instruments for education. They also estimate the effect of education on disability with NLS data, using IQ and family background measures as instruments. In both cases schooling is significant. Using a sample of older persons from the 1986 PSID, Leigh and Dhir (1997) use parental education, background, and state-of-residence at age 16 to instrument for education in regressions for disability and exercise. Alternatively, they include direct measures of time preferences and risk aversion. Education was not always significant. Finally Sander (1995) examines the effect of schooling on the odds of quitting smoking using the General Social Survey. He uses parental schooling as an instrument for schooling and finds that the effect of schooling is quite large for whites.

10 Development studies show that family background affects children's health (see Strauss and Thomas, 1995).

${ }^{11}$ For examples see studies that looked at the consequences of the Dutch famine on the health of adults conceived during the famine, such as Hoek, Brown and Susser (1998) or Roseboom (2000).

12 However this methodology is used in epidemiology. For example see the work by Haines and Preston (1996).
} 
suggest that an additional year of education lowers the probability of dying in the next 10 years by approximately 1.3 percentage points, my results from the IV estimation show that the effect is much larger: at least 3.6 percentage points. However the results also suggest that the OLS and the IV estimates are not statistically different.

This paper is organized as follows. Section 2 describes the data used in this project, including a description of how the census is used to obtain mortality rates. Section 3 shows that compulsory attendance and child labor laws had an impact on the educational attainment of individuals, and presents evidence that these laws are good instruments. Section 4 presents the general econometric framework used for analyzing mortality. The results are presented and discussed in Section 5, and conclusions are given in section 6.

\section{Data}

I use the U.S. censuses of 1960, 1970 and 1980, which are one percent random samples of the population. ${ }^{13}$ The census provides information on age, sex, race, education, marital status, urban location, state of residence and state of birth. My samples include all white persons born in the 48 states, ${ }^{14}$ that were 14 years of age between 1914 and 1939, with no missing values for completed years of education. ${ }^{15}$

I use the censuses to follow "synthetic cohorts." Although I do not observe the same individuals over time (so I cannot observe individual deaths), I do observe the same groups over time, which allows me to estimate group death rates. I aggregate the censuses into groups defined according to their gender/cohort and state-of-birth (descriptive statistics in Table 1). Using the 1960, 1970 and 1980 censuses, I can calculate two 10-year death rates for each group: one for 1960-1970, and another for 1970-1980. For example, the 1960-1970 death rate for a group is the number of people

\footnotetext{
13 The data come from the IPUMS 1960 general sample, the 1970 Form 2 State sample (originally $15 \%$ state sample), and the $19801 \%$ Metro sample (originally B sample).

14 Hawaii and Alaska were not then part of the Union.

15 For consistency across censuses, I recoded completed years of education to be a maximum of 18 years instead of 20 in 1980 .
} 
alive in $1960\left(N_{60}\right)$ minus the number of people alive in $1970\left(N_{70}\right)$ divided by the population in $1960\left(N_{60}\right)$.

One issue that arises in estimating death rates by groups is measurement error. As Figure 3 shows, because of random sampling the number of deaths will be overestimated about half the time and underestimated half the time for all cohorts. As a result, some estimated death rates are negative. In the data, we observe more negative death rates for younger cohorts and fewer negative death rates for older cohorts (see Figure 4A); this is a pattern we should expect. As we can see in Figure 3B, with a zero death rate (no change in the population), two successive samplings of the same population result in a negative death rates half the time. When the death rate increases (as the population ages), the likelihood that the second sample will contain more observations than the first falls, resulting in fewer negative death rates. We also observe fewer negative death rates for states with large population (Figure 4B), which is also to be expected since the sampling error is smaller for larger populations.

The negative death rates are not a source of concern for two reasons. First, the estimated death rates will result in consistent estimates of the true death rates. ${ }^{16}$ Second, average cohort death rates from the censuses are very similar to those obtained from individual data from the NHEFS described below (see Figure 4C). Note that the graph suggests there is evidence of age heaping: for ages that are multiples of 10 , the death rates fall, because individuals tend to over-report their age and chose a multiple of ten when doing so.

I also used the National Health and Nutrition Examination Survey I Epidemiologic Follow-up Study, 1992 (hereafter NHEFS). This survey followed 14,407 individuals who were between 25 and 74 years of age when interviewed for the first National Health and Nutrition Examination Survey (NHANES I) between 1971 and 1974. The NHEFS followed individuals and recorded whether they had died by 1985. The sample is composed of whites ${ }^{17}$ that were 14 years of age between

\footnotetext{
16 Also note that IV estimates are only consistent, not unbiased, estimates of structural parameters. A consistent estimate of the dependent variable is sufficient for the IV estimators to be consistent.

17 Other researchers have suggested that blacks had significantly different school experiences during the begining
} 
1914 and 1939, who were alive in 1975 and followed successfully, with no missing observations for years of completed education $(\mathrm{N}=4554)$. Table 1 shows the summary statistics for this data.

The data on compulsory attendance and child labor laws come from a number of sources. There are eight years of state-level data $(1915,1918,1921,1924,1929,1930,1935$ and 1939) on these laws, ${ }^{18}$ and some additional information for other years. I imputed missing observations by using the older values. I also collected data on state-level factors that contributed to the growth of secondary education from 1915 to $1939^{19}$ or that could affect mortality. These include state expenditures on education, number of school buildings per acre, percent of the population that was living in urban areas, percent of the white population that was foreign born, percent of the population that was black, percent of the population employed in manufacturing, average annual wages in manufacturing per worker, average value of farm property per acre, and number of doctors per capita (See Lleras-Muney 2001 for information on data sources).

Each individual is matched to the laws and state characteristics that were in place in their state-of-birth when they were 14 years old. I choose this age because it is the lowest common drop-out age across states. This procedure assumes that individuals went to school in their stateof-birth. Inevitably some individuals were mismatched. However, Card and Krueger (1992) show that mobility was low during this period. Also Lleras-Muney (2001) shows that mobility seems to be uncorrelated to these laws and that restricting the sample to those that are still living in their state-of-birth does not change the effect of the laws. ${ }^{20}$

of the century. See Card and Krueger (1992). Also, Lleras-Muney (2001) suggests that compulsory schooling laws and child labor laws did not affect blacks.

18 Acemoglu and Angrist (1999) have gathered similar data. The data for this project was collected independently.

19 The state-level variables were suggested by the work of Goldin (1994) and Goldin and Katz (1997).

${ }^{20}$ I regressed mobility between state-of-birth and state-of-residence in1960 as a function of education, compulsory education laws and all other covariates used in this paper. The F statistic of joint significance of the laws has a value of 1.17 ( $\mathrm{p}$ value of 0.3151 ), suggesting the laws cannot explain mobility. Also Lleras-Muney (2001) shows that restricting the sample to those that are still living in their state-of-birth yields estimates of the effect of the laws that are statistically identical to those presented here. 


\section{Did Compulsory Attendance and Child Labor Laws affect schooling? First Stage}

The validity of the methodology proposed in this paper rests on the crucial assumption that compulsory attendance laws and child labor laws can be used as instruments. This section estimates the first stage, showing that the laws are good predictors of educational attainment both at the individual and aggregate level. I also provide additional evidence here that the laws are good instruments. These results will then be used in the two-stage (IV) estimations in Sections 4 and 5.

\subsection{Compulsory Attendance and Child Labor Laws}

Since their inception in Massachusetts in 1852, compulsory attendance laws have been complex. They specify a minimum and a maximum age between which school attendance is required; a minimum period of attendance; penalties for non-compliance; and the conditions under which individuals could be exempted from attending school, such as the completion of a given grade, mental or physical disability, distance from school, and so on. The most common exemption was for work. Work permits were available even for young children, generally even younger than the minimum dropout age specified by compulsory education laws. Child labor laws, which extensively regulated the employment of minors, also included several conditions for the granting of such permits and for exemptions.

Child labor laws and compulsory attendance laws often were not coordinated. Each stipulated different requirements for leaving school. For example, in 1924 in Pennsylvania, the ages for compulsory attendance were 8 to 16 , but the child labor laws allowed 14 year-olds to get work permits and leave school. ${ }^{21}$ Continuation school laws, which forced children at work to continue their education on a part-time basis, were the only laws that attempted to bridge this gap. Compulsory attendance laws and child labor laws were in place in all states by 1918, and were modified

${ }^{21}$ During this early period work permits effectively allowed children to leave school. See Woltz (1955). 
frequently thereafter.

There is little agreement regarding the effectiveness of these laws. ${ }^{22}$ Previous studies (including my own $)^{23}$ suggest that only three of the many aspects of these laws had an impact on individual educational attainment: the age at which a child had to enter school (enter age), the age at which the child could get a work permit and leave school (work age), and whether or not the state required children with work permits to attend school on a part-time basis (contsch). Following Acemoglu and Angrist (1999), I combine the age at which a child had to enter school and the age required for work permit into a single variable, childcom, defined as: childcom $=$ work age - enter age. This variable is the implicit number of years that a child had to attend school, given that the entering age and the work permit age were enforced. It takes the values of $0,4,5,6,7,8,9$, or 10 . The other variable, contsch, takes the value of 1 if continuation school laws were in place. Tabulations describing these laws throughout the period for each state are shown in the Appendix. Importantly note that it is not always the case that more years of compulsory schooling were required, although on average states required more schooling towrds the end of the period.

The period from 1915-1939 is when compulsory education laws (hereafter I refer to both compulsory attendance laws and child labor laws as "compulsory education laws") are more likely to have affected many individuals. Secondary schooling was experiencing remarkable growth, especially in the first 40 years of this century. ${ }^{24}$ Also, in the previous period (up to 1915), these laws were perceived as ineffective. ${ }^{25}$ But social scientists agree that the laws were enforced by the $1920 \mathrm{~s}^{26}$ and Schmidt's work (1995) — the only study to concentrate on this period - confirms it.

\footnotetext{
${ }^{22}$ For a detailed review of these studies see Lleras-Muney (2001).

23 See Lleras-Muney (2002), Angrist and Acemoglu (1999) and Schmidt (1996).

${ }^{24}$ Goldin and Katz (1997) show that the percentage of young adults with high school degrees increased from 9 percent in 1910 to more than 50 percent in 1940.

${ }^{25}$ Many state laws did not even provide enforcement mechanisms, and if they did, there were often insufficient means to enforce them, especially in rural areas. See Katz (1976) and Ensign (1921)

${ }^{26}$ See $\operatorname{Katz}(1976)$.
} 
Edwards (1978), and Angrist and Krueger (1991) suggest that the laws declined in importance after the 1940s. So the first part of the 20th century provides the perfect window of opportunity for using the laws as instruments. Finally, from a technical point of view, this period is interesting because states were constantly changing their compulsory education and child labor laws.

\subsection{The effect of the laws on educational attainment}

As preliminary evidence of the effect of these laws on education, I graph the average education by childcom for the entire sample (Figure 5) and by cohort, for every 5th cohort in the data (Figure 6). Both graphs show that average education is higher for those in states where more education was compulsory. In order to add further controls, I turn to regression analysis. Pooling individual data from the 1960 and 1970 census, I estimate the following model:

$$
E_{i c s}=b+C L_{c s} \pi+X_{i c s} \beta+W_{c s} \delta+\gamma_{c}+\alpha_{s}+\varepsilon_{i c s} .
$$

The dependent variable is years of completed education for individual $i$ of cohort $c$ born in state $s$. CL is a set of dummies for compulsory education laws in place in state $s$ when the individual was $14, X_{i c s}$ are individual characteristics such as gender and region of current residence, $W_{c s}$ is a set of characteristics of individual $i$ 's state-of-birth at age 14 (such as manufacturing wages, expenditures in education, per capita doctors, etc.), $\gamma_{c}$ are cohort dummies, $\alpha_{s}$ are state-of-birth dummies. The regression also includes interactions between region-of-birth and cohort, an intercept $(b)$ and a dummy for 1970. I also estimate the model by aggregating the data at the state-of-birth/cohort and gender level. Both estimations will be used in Section 4 (first stage).

Table 2 shows the results. The first column estimates the relationship including only state effects, cohort effects, a female dummy, and a set of dummies for the laws. The coefficients are fairly robust to the addition of other controls (see column 2) ${ }^{27}$ The last column shows the results from estimating the equation using the data aggregated at the state-of-birth, cohort and gender

\footnotetext{
27 Inclusion of other variables, such as income, immigrant status of parents, has no impact on them. Also, regressions by region-of-birth or by gender yield similar results. See Lleras-Muney (2001) for these results.
} 
level. The estimations show that the laws increased the educational attainment of individuals. As expected, all dummies for the laws are positive and significant and they generally increase as the number of compulsory years increases. Overall, the implied increase in educational attainment due to childcom is around 4.8 percent. ${ }^{28}$ This estimate is similar to those reported by Acemoglu and Angrist (2000), Eisenberg (1988) and Angrist and Krueger (1991). Also, the continuation school dummy is positive. ${ }^{29}$

Before turning to the effect of education on mortality, I present evidence that the laws are good instruments. At the bottom the Table 2, I report the F-test of joint significance of the laws; it shows that the laws are always jointly significant at the $5 \%$ level for both specifications. Additionally the F-statistic is greater than (or very close to) 5, which suggests that the instruments are strong. I also report the partial R-squared coefficient, another measure of the instruments' strength. ${ }^{30}$ It has a value of 0.0001 or higher, which compares favorably to those reported by Bound, Jaeger, and Baker (1995).

It is also worth pointing out that the changes in the laws that took place during this period appear to have been exogenous to individuals. Although different states might have had different tastes for education, the regressions here include a very large set of controls (cohort dummies, stateof-birth dummies and region-of-birth*cohort interactions are included) which should capture this effect. Also note that the addition of controls (compare column 1 and 2 of Table 2) has little effect on the coefficients of the laws, suggesting that any excluded state-of-birth/cohort level variables are not correlated with the laws. Furthermore, Lleras-Muney (2001) presents evidence consistent with exogenous laws: her results suggest that the laws impacted only the lower end of the distribution of education. She rejects the hypothesis that changes in the laws during this period resulted from

\footnotetext{
28 This was calculated by replacing the set of dummies by the continuous variable. See Lleras-Muney (2001).

29 Continuation school is not significant in this sample, but previous work (see Lleras-Muney, 2001) showed that this law affected white males and individuals born in the north and south of the U.S. Therefore I include it.

30 Bound, Jaeger, and Baker (1995) suggest that: 1-the F statistic on the excluded instruments in the first stage should be statistically significant and large (Staiger and Stock (1997) further suggests that a value of less than 5 could signal weak instruments. This is a rule of thumb); 2-the partial r-square should be high.
} 
(rather than caused) increases in education. ${ }^{31}$

A final concern is that the laws must affect individual health only through their effect on education. There is no evidence that the laws included any clauses or restrictions that would have affected health independently. For example, there were no lunch programs provided as part of school attendance. Also the states that led in education during this period (the prairie states ${ }^{32}$ ) were not the same states that led in health (northeastern states). ${ }^{33}$ But again, the controls included here are meant to rule out this possibility. Finally, exogeneity tests are performed in the IV estimation (see next section).

Overall the results show that the laws did have an impact on educational achievement, and that their predictive power is large, so they can be used as instruments. Therefore I turn now to the question of the effect of education on mortality.

\section{Health and Education: Econometric model}

\subsection{Least Squares Estimation}

The econometric model for the relationship between education and health can be written as a linear system of simultaneous equations:

$$
\begin{aligned}
& H_{i}=X_{1 i} \beta_{1}+E_{i} \pi_{1}+\varepsilon_{1 i} \\
& E_{i}=X_{2 i} \beta_{2}+H_{i} \pi_{2}+\varepsilon_{2 i},
\end{aligned}
$$

where $H_{i}$ is individual $i$ 's health stock, $E$ is his education level, $X_{1}$ is a vector of individual characteristics that affect health, such as smoking, and genetic factors. $X_{2}$ is a vector of individual characteristics that determine education, such as ability. $X_{1}$ and $X_{2}$ may contain common factors.

\footnotetext{
31 The test, inspired by Landes and Solomon (1972), consists of matching individuals to the laws in place in their state-of-birth when they were 17, 18 and up to 26 years of age, when these laws should no longer have affected them.

32 See Goldin and Katz (1997).

33 Starr's 1982 book provides anecdotal evidence that the northern states lead in a variety of health aspects. My own data supports this conclusion. For example, the north had the highest number of doctors per capita throughout the period. And the number of doctors per capita in the north did not decline from 1915 to 1939 but did decline in the rest of the country. The north also had the highest declines in infant mortality rates during this period. (Results available upon request.)
} 
This general specification allows for causality to run from education to health and vice-versa. The purpose of this paper is to determine only whether or not education affects health (i.e. $\left.\pi_{1}=0 ?\right)$. Therefore I only estimate the health equation. Although health is unobserved, mortality is observable. Following Grossman's model of health (reviewed in his 1999 paper), death occurs when the stock of health falls bellow a certain threshold. In a less deterministic model, $H_{i}$ is proportional to the underlying probability (index) of being alive, and death is the observed result. This is the usual limited-dependent variable set-up.

This mortality equation can be estimated at the individual level using the NHEFS but not the census. If individuals could be followed from the 1960 census to the 1970 census (or from 1970 to 1980), then (based on the previous discussion) the following individual linear probability model could be estimated:

$$
D_{t, i c s}=b+E_{i c s} \pi+\left(X_{t-1}\right)_{i c s} \beta+W_{c s} \delta+\gamma_{c}+\alpha_{s}+\varepsilon_{i c s}
$$

where $\mathrm{D}_{t i}$ is equal to one if the individual is deceased at time t. $E_{i c s}$ is $i$ 's education (measured by completed years of education), $\mathrm{X}_{t-1}$ are other individual characteristics measured as of ( $\left.\mathrm{t}-1\right)$ (including gender), $W_{c s}$ is a set of characteristics of individual $i$ 's state-of-birth at age $14, \gamma_{c}$ is a set of cohort dummies, $\alpha_{s}$ is a set of state-of-birth dummies, $b$ is an intercept, and $\varepsilon$ is the error term.

Using the census, individuals cannot be tracked over time, but I can track groups that are constant over time, and calculate their death rates by aggregating the data. I aggregate by gender, cohort, and state-of-birth. This aggregation level uses all of the available individual characteristics that are time invariant (except for education), and therefore it maximizes the number of observations in the aggregate data. The aggregate model is derived from the individual model by averaging over individuals in a given gender/cohort/state-of-birth group as follows:

$$
{\overline{D_{t g c s}}}=b+\bar{E}_{g c s} \pi+{\overline{\left(X_{t-1}\right)}}_{g c s} \beta+W_{c s} \delta+\gamma_{c}+\alpha_{s}+\bar{\varepsilon}_{g c s}
$$

where $\bar{D}_{\text {tgcs }}$ represents the proportion of individuals that died in a given group or the death 
rate for that group, and $\bar{X}_{t-1}$ gcs represents the average characteristics of that group at $(t-1)$ (for example, the the percentage of people in that group living in urban areas). ${ }^{34}$

Note that I use a linear probability model for the estimation. The existence of negative death rates makes it impossible to use a non-linear model such as a Logit or Normit. However, since the dependent variable (the death rate) is not censored below by 0 , the linear probability assumption is less problematic in this case than in general. In this linear model the error term is heteroskedastic however. A standard estimation procedure ${ }^{35}$ in this case is to run weighted least squares, where the weights are constructed using the observed probablities. Again, due to random sampling and the error it generates, these observed probabilities can be negative, so this estimation is not possible. In order to address the heteroskedasticity problem I estimate the equation by GLS (weighted least squares) using the number of individuals in the group as weights. To correct for further heteroskedasticity, I use White's estimator.

\subsection{Efficient Wald estimates}

One obvious solution to correct for the bias in the GLS coefficient is to use Instrumental Variables (IV). Given that many instruments are available, Two Stage Least Squares (2SLS) would be the preferred estimation method. At the individual level, the 2SLS model is:

$$
\begin{aligned}
D_{t i} & =b+E_{i c s} \pi+\left(X_{t-1}\right)_{i c s} \beta+W_{c s} \delta+\gamma_{c}+\alpha_{s}+\varepsilon_{i} \\
E_{i c s} & =b+C L_{c s} \pi+\left(X_{t-1}\right)_{i c s} \beta+W_{c s} \delta+\gamma_{c}+\alpha_{s}+\varepsilon_{i c s}
\end{aligned}
$$

where $\mathrm{D}$ is equal to one if the individual is deceased at time t. $E$ is $i$ 's education (measured by completed years of education), $\mathrm{X}_{t-1}$ are other individual characteristics measured as of (t-1) (including gender), $W_{c s}$ is a set of characteristics of individual $i$ 's state-of-birth at age $14, \gamma_{c}$ is a set of cohort dummies, $\alpha_{s}$ is a set of state-of-birth dummies, $b$ is an intercept, and $\varepsilon$ is the error term, which is assumed to be normal $\mathrm{N}\left(0, \sigma_{1}^{2} I\right)$. CL is the set of compulsory education laws that

\footnotetext{
${ }^{34}$ Including a dummy for gender.

35 See Maddala p. 29, Green p. 895.
} 
serve as instruments to identify the education equation. This model can be estimated using the individual NHEFS data but not with the census.

Since the census data can be used only as grouped data, the Wald estimator is an alternative estimator for the effect of education. Angrist (1991) showed that the Wald estimator for grouped data is efficient and in fact equivalent to 2SLS using individual level data. In the case of many explanatory variables the efficient Wald estimator is found by GLS estimation of the following equation:

$$
\bar{D}_{c r l}=\bar{E}_{c r l} \pi+\gamma_{c}+\delta_{r}+\bar{\varepsilon}_{c r l}
$$

where $\bar{D}_{c r l}$ is the death rate for individuals born in cohort $c$ in region $r$ under compulsory law $l$, and $\bar{E}_{c s l}$ is the average education of individuals born in cohort $c$ in region $r$ under compulsory law $l$. The weights are given by the population in each group. In other words, Wald is estimated by grouping the data by gender/cohort/region-of-birth and compulsory education law. This procedure is equivalent to 2SLS at the individual level, where gender, cohort dummies and region dummies serve as their own instruments (since they are exogenous), and compulsory education laws serve as instruments for education, the endogenous variable. The estimates are referred to as the efficient Wald estimates.

Note that because compulsory education laws are defined at the state-of-birth and cohort level, I cannot control for both state-of-birth and cohort when using this estimator. This is a drawback of the Wald estimator, especially if one thinks that state-of-birth and the laws are correlated. In order to alleviate this problem, I control instead for region-of-birth. But region-of-birth may not be a good proxy for state-of-birth. Furthermore, other individual $\left(X_{t-1}\right)$ and state-of-birth characteristics $\left(W_{c s}\right)$ cannot be included in this specification.

\subsection{Two-Stage Least Squares with Aggregate Data}

Alternatively, I can estimate the 2SLS model at the data that has been aggregated at the state-ofbirth/cohort and gender level. Estimation at the aggregate level results in less efficient estimates 
(see Green pp. 433-434) but all the covariates (especially state-of-birth) can be included. Using the aggregate data 2SLS is obtained by estimating the following model:

$$
\begin{aligned}
& \bar{D}_{g c s}=b+\bar{E}_{g c s} \pi+\bar{X}_{t-1}^{g c s} \beta+W_{c s} \delta+\gamma_{c}+\alpha_{s}+\bar{\varepsilon}_{g c s} \\
& \bar{E}_{g c s}=b_{1}+C L_{c s} \pi+\bar{X}_{t-1}{ }_{g c s} \beta+W_{c s} \delta+\gamma_{c}+\alpha_{s}+\bar{\varepsilon}_{g c s}
\end{aligned}
$$

where now $\overline{D_{t g c s}}$ is the proportion of individuals who died in a given gender/cohort and state-ofbirth, $\bar{E}_{g c s}$ is the average education of that group and ${\overline{\left(X_{t-1}\right)}}_{g c s}$ are other average characteristics. Again, the weights are given by the number of observations in each cell, and the excluded instruments from the mortality equation are the compulsory education dummies, $C L_{c s}$. The first stage (estimation of $\bar{E}_{g c s}$ ) was shown in the previous section.

\subsection{Mixed Two-Stage Least Squares Estimation}

The census allows me to estimate the first stage using individual data. The intuition behind Mixed-2SLS is that it might be possible to take advantage of this fact and gain efficiency (relative to the previous 2SLS) by estimating the first stage at the individual level (as done in the previous section) and then aggregating the data by gender/cohort/state-of-birth. (See Dhrymes and LlerasMuney, 2001. $)^{36}$ Mixed 2SLS is obtained by estimating the following equation through weighted least squares:

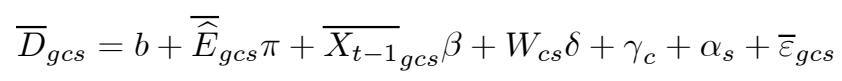

Again $\bar{D}_{g c s}$ represents the proportion of individuals who died in a given gender/cohort and state-of-birth group, $\bar{X}_{g c s}$ represents the average characteristics of the group, but now I include $\widehat{E}_{g c s}$, the average predicted education for that group from the first stage. ${ }^{37}$ The weights are given by the number of observations in each cell. The excluded instruments from the mortality equation are the compulsory education dummies. The only difference between standard 2SLS with

\footnotetext{
36 Dhrymes and Lleras-Muney (2001) compare 2SLS and Mixed 2SLS estimators. The question of which estimator has lower variance turns out to be data dependent, but it is possible for Mixed 2SLS to be more efficient.

37 The expression for the first stage was given in the previous section.
} 
aggregated data and Mixed-2SLS is in the predicted education term. 2SLS uses predicted average education whereas Mixed-2SLS uses average predicted education.

More formally, let $\mathrm{H}$ be the matrix that transforms the data into group means and weights each group mean by the number of individuals in the group. $\widehat{X}$ contains all the same variables as in the GLS estimation, but with education replaced by the predicted level of education from the first stage regression $\left(\widehat{X}=\left[\bar{E}\left|\overline{X_{t-1}}\right| \gamma_{c} \mid \alpha_{s}\right]\right.$. Then the estimator $\beta_{\text {Mixed }}$ can be expressed as:

$$
\beta_{\text {Mixed }}=\left(\widehat{X}^{\prime} H^{\prime} H \widehat{X}\right)^{-1} \widehat{X}^{\prime} H^{\prime} H D
$$

This procedure also results in consistent estimates. As usual the variance-covariance matrix needs to be corrected. ${ }^{38}$

\section{$5 \quad$ Results}

\subsection{Least Squares Results}

Although we have good reason to believe that GLS produces biased estimates, I report them here as the benchmark for comparison with the IV results. Using the census, I estimate the GLS model described above. The results are in the first column of Table 3. The estimated coefficient of the effect of education on the death rate is about -0.012 . The coefficient is highly significant and is is robust to the inclusion of more controls. ${ }^{39}$

The validity of the aggregation procedure rests on the assumption that the aggregate data can be understood as coming from unobserved individual data. It is important that this intuition be confirmed, so I compare aggregate results from the census with those obtained with the NHEFS individual data. Using individual NHEFS data, I estimate a linear probability model and a probit model, where the dependent variable is a dummy indicating whether or not the person died between 1975 and 1985. Then I aggregate the NHEFS data by gender, state-of-birth, and cohort and again estimate the same linear model estimated with the census data. Because of the small

38 The standard errors were bootstrapped using 2000 replications.

39 Results available upon request. 
number of observations in the NHEFS aggregating by gender, state-of-birth and cohort results in very few observations per cell, so I also reproduce the results only aggregating by state-of-birth and cohort. The results are shown in Table 3 .

Comparing the results from LS regressions from the census with results from the NHEFS shows that the census data gives extremely accurate estimates of the effect of education. The census LS estimates are very similar to those obtained using the NHEFS aggregated data, which in turn are similar to those obtained at the individual level, using either LS or probit estimations. These results suggest that sampling (and the measurement error it generates) does not significantly affect the estimates for education, that there is no aggregation bias and that the linear model is a good approximation of the education-death rate relationship. The comparison is also useful in terms of interpretation: a -0.012 coefficient for education means that increasing the education of a given cell by one year lowers its death rate by 1.2 percentage points. This coefficient also implies that increasing an individual's education by one year will lower his probability of dying between 1960 and 1970 (or between 1970 and 1980) by 1.2 percentage points. This latter interpretation is more intuitive and useful. Note again that the OLS effect is quite large: at the mean, this result implies that a 10 percent increase in education lowers mortality by about 11 percent, therefore an elasticity of about -1 .

\subsection{IV results}

The first column in Table 4 presents the 2SLS results using the NHEFS. This estimation is done at the individual level and using standard 2SLS. The estimate is positive (the effect of education is about -0.02 ) but not significant: because this sample is small, the first stage estimation ${ }^{40}$ is poor. Nonetheless, although the standard errors are high, the estimates from this sample are also larger than the GLS estimates obtained from the same data.

The second column shows the results from the Wald estimation. The Wald estimate of the effect

\footnotetext{
${ }^{40}$ Results available upon request. Only two of the dummies for compulsory education laws were significant at the $10 \%$ level, and the set of dummies was jointly insignificant.
} 
of education is about -0.037 and significant at the 5 percent level. The third column presents the results of 2SLS estimation using aggregated data at the gender/state-of-birth-and cohort level. The effect of education is about -0.045 and significant at the 10 percent level. The Mixed 2SLS results (last column) show that the coefficient on education is approximately -0.059 and is significant at the 5 percent level. All of the previous estimates are significant at the $5 \%$ level using a one-tailed test (that the effect is negative) which is perhaps more appropriate in this set-up. ${ }^{41}$ Overall the results suggest that increasing education by one additional year lowers the 10-year death rate by at least 3.6 percentage points. ${ }^{42}$

For the last two estimators I perform a test of overidentifying restrictions. The $\chi^{2}$ statistic for the aggregate 2SLS model is 2.42 and 1.49 for the Mixed 2SLS model. This statistic tests the hypothesis that the model is well specified. It is calculated as the sample size times the $\mathrm{R}^{2}$ from a regression of the residuals from the second stage on all exogenous variables, including the instruments. In both cases the overidentifying restrictions are not rejected at a 5 percent level (critical value 14.06). This test in conjunction with earlier results from the first stage suggests that compulsory education laws are legitimate instruments.

Additional checks are presented in Table 5. As a last attempt to address the potential endogeneity of the laws, I repeat the estimations above using a larger set of instruments that include quarter of birth, compulsory attendance and child labor laws, and the interactions of quarter of birth and the laws. Presumably these individual-level instruments will increase the efficiency of the estimates, and they are perhaps less likely to be endogenous. ${ }^{43}$ The results (Panel A) are identical to those presented above. The results are also very similar if only the interactions between the laws and quarter of birth are used as instruments, and quarter of birth as well as

\footnotetext{
41 I thank Michael Grossman for this insight.

42 Estimates by region are comparable in size to those presented here except that they are generally not significant.

43 Note however that the use of these instruments might be questionable (see papers in footnote 10). Also Lleras-Muney (2001) shows for example that the laws affected whites but not blacks. However quarter of birth does appear to affect blacks' educational attainment. This again raises the issue of whether quarter of birth has an independent effect on education unrelated to compulsory attendance laws.
} 
compulsory schooling laws are included as controls in both the first and second stage. ${ }^{44}$ This again suggests that the instruments are not endogenous.

Panel B presents the reduced form estimates, i.e. the direct effect of the laws on mortality. The results are consistent with previous estimations: if the effect of childcom on education is about 5 percent, and the effect of education on mortality is about 6 percent, then the direct effect of the laws on mortality should be about 0.3 percent, which is approximately what the reduced form result shows.

Panel $\mathrm{C}$ shows the results excluding ages 40, 50 and 60 since the data showed evidence of age heaping. This is a potential problem if age heaping is correlated with education. The IV results are very similar to the previous results. Finally in Panel D I repeat the estimations by region of birth. They are quantitatively identical to all the results presented before. So the previous estimates are not purely based on differences between regions.

Since, it is well known that there exist persistent differences in mortality rates by gender I reproduce results by gender in Table 6 . The coefficient on education is somewhat smaller for females than for males, confirming the findings in the literature that the effect of education is larger for males. These results also suggest that World Wars I and II did not results in significant selection bias for men. Also, in these estimations the effect of marriage is negative as the literature suggest, whereas the effect is positive in the joint estimations. This is a composition effect: males are both more likely die and to be married.

\subsection{Discussion}

This section has presented four different estimates of the effect of education on mortality. Three different estimators, using two different data sets and three different levels of aggregation, were used. Although each estimate has weaknesses, all estimates point to the same conclusion: the effect of education is causal and in fact larger than OLS suggests. Given this variety of estimates,

\footnotetext{
${ }^{44}$ Results available upon request.
} 
this result is very robust. The result is surprising for two reasons. The first is that the IV estimates are larger than the LS estimates. The second is that the effect of education is quite large. In this section I discuss these two issues.

\subsubsection{Larger IV estimates}

In all the IV estimations presented here, the effect of education is much larger than the LS estimates suggest. The Mixed 2SLS estimates suggest the effect is as large as -0.058 , whereas Wald estimates imply a coefficient of about -0.036. At first, this could seem to be a surprising result: the a priori expectation was that LS estimates would be too large. However there are two important points to notice.

First note that the standard errors in the IV estimates are large. Even though the IV estimates are significantly different from 0 , it is unclear whether they are statistically different from the OLS estimates. To test whether the IV and OLS estimates are different, one can perform a DurbinWu-Hausman test. The F-statistic for this test is 1.51 (p-value 0.22 ). Therefore I cannot reject the null hypothesis that OLS and IV are the same.

Note that an implication of this test is that education is in fact exogenous, since it suggests that the IV estimates are no different from the OLS estimates in a statistical sense. From this test, I conclude that education appears to have a large causal effect on mortality. Furthermore, I conclude that the larger IV estimates are not of particular concern.

However, if one still thought that education was endogenous, then the most plausible explanation for the difference between the IV and the OLS estimates in this case is related to the choice of instrument. ${ }^{45}$ Under the assumption that different individuals face different returns to education due to unobserved characteristics, IV estimates reflect the marginal rate of return of the

\footnotetext{
45 Another explanation is that the omitted variable bias is smaller than the bias that results from measurement error in education (Card 1995) The health literature has not been concerned with this potential problem although there is evidence of measurement error in education. If the measurement error is random, then IV estimate will be larger than the OLS estimate. Larger IV returns can also be explained if there exist health externalities from education for example if average education affects individual health. However note that the fact that individual and agregate estimations using the NHEFS result in similar effects for education suggests that externalities are not the main reason for larger IV.
} 
group affected by the instrument (Angrist, Imbens and Rubin, 1996), in this case IV capture the returns to those affected by the compulsory schooling laws. If I estimate a regression of mortality as a function of education and education squared, where both are instrumented with compulsory schooling laws, I do indeed find some evidence that the relationship is convex. However I do not place too much weight on these results given that a) under the hypothesis that education is endogenous, the instruments can only identify a non-linear relation for those affected by the laws, rather than for the population at large, and b) education does not appear to be endogenous!

\subsubsection{What is the effect of education on health?}

The second issue is that the effect of education is quite large, and it is important to understand why. I categorize the potential effects of education into two categories: direct and indirect effects.

Among the direct effect, education provides individuals with critical thinking skills that are useful in the production of health (Grossman's hypothesis). There is some evidence to this effect. For example, Goldman and Smith (2001) find that the more educated are more likely to comply with treatments for diabetes and Aids. Goldman and Lakdawalla (2001) suggest that the more educated are better able to manage chronic conditions. These two papers suggest that education matters when treatments are complex and there is scope for learning by doing. These mechanisms have also been documented by Rosenzweig and Schultz (1989), who compared success rates of different contraception methods for women with different levels of education: they find that success rates are identical for all women for "easy" methods such as the pill, but the rhythm method is only effective for educated women.

If this is the case, then the interaction of education with a variety of factors might be relevant. For example, although access to information alone cannot explain health differences across education groups (Kenkel, 1991), information available to the more educated will result in greater benefits for them if they can use the information better. For example when analyzing the effects of the 1964 Surgeon General Report, Meara (2001) concluded that "the response to knowledge 
plays a more important role than knowledge itself in creating differential health behavior".

Another possibility is that the more educated might be more likely to adopt and use new medical technologies. ${ }^{46}$ Since the rate of medical innovation dramatically increased in the last century, especially for particular diseases such as heart disease (Cutler et al. 1998), it is reasonable to think that the more educated were able to capture very high returns during this period. LlerasMuney and Lichtenberg (2001) for example show that the more educated are more likely to use newer drugs.

There are a few indirect mechanisms through which education might affect health which are also consistent with the results in this paper. One obvious one is that being in the classroom is less of a health risk than working, especially while growing up. I cannot with my data distinguish the effect from not working from that of being in school.

Also note that education gives you access to a higher income and different types of jobs, both of which affect health. For example, only high school graduates in the first half of the century had access to white collar jobs, which provided healthier work environments than manufacturing or agriculture. Controlling for income (or occupation) does not change the results in this paper (results are presented in Table 7). But, since income is endogenous, it is not possible (given that I have no instruments for income) to distinguish the direct effect of education on health from its indirect effect through income. The same is true for occupation. However, Grossman (1975) showed that the effects of income on health disappear once a certain level of income has been reached, while the same is not true for education. Furthermore, standard results suggest that the returns to education are about $10 \%$ and that the elasticity of mortality with respect to income is about $-0.3 .{ }^{47}$ If the sole effect of education is through income, one more year of education should

\footnotetext{
46 See Nelson and Phelps (1966)

47 Deaton and Paxson (1999).
} 
decrease mortality by 0.003 (for average mortality of 0.11 ), ${ }^{48}$ which is a much smaller effect than what was estimated here. With respect to occupation, I simply note here that since the effect of education is similar for men and women, it would appear that occupation is not the only channel through which education affects health.

Finally note that the cognitive psychology literature has documented that lack of education is correlated with stress, depression and hostility, all of which have been shown to adversely affect health (Adler et al, 1994).

A final comment is that the results in this paper do not imply that time preferences do not affect health and education choices nor that there is no reverse causality from health to education. They simply show that there is a causal effect of education on health, and that this effect is not due to time preferences. However, as Becker and Mulligan (1997) argue, education could lower the discount rate, making people more patient. This is yet another indirect mechanism that could explain my results.

\section{Conclusion}

This paper has shown that there is a large causal effect of education on mortality. While GLS estimates suggest that an additional year of education lowers the probability of dying in the next 10 years by approximately 1.3 percentage points, my results from the IV estimation show that the effect is perhaps much larger: at least 3.6 percentage points. However it is worth noting that the OLS and the IV estimates are not statistically different. Nonetheless the effects are

\footnotetext{
48 The calculation is done as follows: Deaton and Paxson (1999) estimate that

$$
\log \left(\frac{d}{1-d}\right)=-0.3 \log (\text { inc })
$$

Studies in labor have found that

$$
\log (\text { inc })=0.1 e d
$$

so by replacing I find that:

the marginal effect is given by

$$
\log \left(\frac{d}{1-d}\right)=-0.03 e d
$$

$$
\frac{\partial d}{\partial e d}=-0.03 d(1-d)
$$

Evaluated at the mean (i.e for $\mathrm{d}=0.11$ ) this effect is about -0.003
} 
large. To better understand the impact of education, I calculate how this effect translates into life expectancy gains. I find that in 1960, one more year of education increased life expectancy at age 35 by as much as 1.7 years (using the OLS estimate). This is a very large increase.

A few notes of caution on how to interpret these results for public policy purposes are necessary. First, in order to make policy recommendations, we need to know more about the specific mechanisms by which education affects health. This paper analyzes the effects of increasing education from relatively low initial levels. It is unclear what the effects would be at higher initial levels of education. The average education level for white Americans born in 1901 was at most 8.87 years. ${ }^{49}$ Today many developing countries, including most Latin American countries, have average levels of education that are similar. This paper implies that more aggressive education policies could dramatically increase adult longevity in such countries. But cost benefit analysis of such policies are extremely complex, since for example we do not know what the cost of increasing education would be, or its effectiveness. Questions such as these are beyond the scope of this paper. But the results presented here suggests that the benefits of education are large enough that we need to consider education policies more seriously as a means to increase health, especially in light of the fact that other factors, such as expenditures on health, have not been proven to be very effective.

This evidence that education increases life expectancy implies that the returns to education, measured only in terms of earnings increases, substantially underestimate the true returns to education. In view of the large magnitude of the effect of education on health, it is clear that more attention needs to be devoted to the pathways of influence. Existing models of the relationship between education and health are very imprecise about the mechanisms through which education operates on health.

\footnotetext{
49 This is the average education level of that cohort in 1960. Data for the entire population in 1901 does not exist for the US, but the average was probably much lower.
} 


\section{References}

Acemoglu, Daron and Joshua Angrist, "How Large are the Social Returns to Education? Evidence from Compulsory schooling Laws," NBER Working Paper No. W7444, December 1999

Adler, Nancy E. et al, "Socioeconomic Status and Health, the Challenge of the Gradient," American Psychologist, vol 49, No. 1January 1994

Angrist, Joshua D., "Grouped Data Estimation and Testing in Simple Labor Supply Models," Journal of Econometrics, February-March 1991

Angrist, Joshua D. and Alan B. Krueger, "Does Compulsory School Attendance Affect Schooling and Earnings?," Quarterly Journal of Economics, November 1991

Angrist, Joshua D., Guido W. Imbens and Donald B. Rubin, "Identification of Causal Effects Using Instrumental Variables," Journal of the American Statistical Association, June 1996

Auster, Richard, Irving Leveson and Deborah Sarachek, "The Production of Health, An Exploratory Study," Journal of Human Resources 4, 1969

Becker, Gary S. and Casey B. Mulligan, "The Endogenous Determination of Time Preference," Quarterly Journal of Economics, August 1997

Berger, Mark C. and J. Paul Leigh "Schooling, Self Selection and Health," Journal of Human Resources 24, 1989

Bound, John, David A. Jaeger and Regina Baker, "Problems with Instrumental Variables Estimation when the Correlation Between the Instruments and the Endogenous Explanatory Variables is Weak," Journal of the American Statistical Association, 90, June 1995

Bound, John, and David A. Jaeger, "On the Validity of Season of Birth as an Instrument in Wage Equations: A Comment on Angrist and Krueger's "Does Compulsory School Attendance Affect Schooling and Earnings"," NBER Working Paper 5835, November 1996

Card, David, "Estimating the Returns to Schooling: Progress on some Persistent Econometric Problems," NBER Working Paper no.W7769, June 2000

Card, David, "Earnings, Schooling, and Ability Revisited," Research in Labor Economics, vol. 14,1995

Card, David and Alan Krueger, "Does School Quality Matter? Returns to Education and the Characteristics of Public Schools in the United States," Journal of Political Economy 100, January 1992

Christenson, Bruce A., and Nan E. Johnson, "Educational Inequality in Adult Mortality: An Assessment with Death Certificate Data from Michigan," Demography 32. May 1995

Currie, Janet and Rosemary Hyson, "Is the Impact of Health Shocks Cushioned by Socioeconomic Status? The Case of Low Birth weight,"American Economic Review, May 1999

Cutler, David, Mark McClellan, and Joseph Newhouse, "The Costs and Benefits of Intensive Treatment for Cardiovascular Disease," NBER Working Paper No.w6514

Deaton, Angus and Christina Paxson, "Mortality, Education, Income and Inequality among American Cohorts," NBER Working Paper 7140, May 1999 
Dhrymes, Phoebus and Adriana Lleras-Muney (2001), "Estimation of Models with Group Data by Means of '2SLS'," mimeo, Columbia University, 2001

Duleep, H.O., "Measuring the Effect of Income on Adult Mortality Using Longitudinal Administrative Record Data," Journal of Human Resources 21, 1986

Edwards, Linda N., "An Empirical Analysis of Compulsory Schooling Legislation, 19401960," Journal of Law and Economics, April 1978

Eisenberg, M.J. (1988) "Compulsory Attendance legislation in America, 1870 to 1915," Ph.D. Dissertation, University of Pennsylvania

Elo, Irma T. and Samuel H. Preston, "Educational Differentials in Mortality: United States, 1979-85," Social Science and Medicine 42(1), 1996

Ensign, Forest Chester, "Compulsory School Attendance and Child Labor," Iowa City, IA: The Athens press, 1921

Farrell, P. and Victor R. Fuchs, "Schooling and Health: The Cigarette Connection," Journal of Health Economics, 1982

Filmer, Deon and Lant Prichett, "Child Mortality and Public Spending on Health: How Much does Money Matter?," World Bank Policy Research Working Papers 1864, December 1997

Fuchs, Victor R., "Time Preference and Health: An Exploratory Study,: in Victor Fuchs, Ed., Economic Aspects of Health, Chicago: The University of Chicago Press, 1982

Goldin, Claudia, "How America Graduated From high School: 1910 to 1960," NBER Working Paper No 4762, 1994

Goldin, Claudia and Lawrence Katz, "Why the United States Led on Education: Lessons from Secondary School Expansion, 1910 to 1940, "NBER Working Paper 6144, August 1997

Goldman, Dana P. and James P. Smith, "Can Patient Self-Management Exaplin the SES Health Gradient," RAND Working Paper, June 2001

Goldman, Dana P. and Darius Lakdawalla, "Understanding Health Disparities Across Education Groups," NBER Working Paper 8328, June 2001

Green, William H., Econometric Analysis, 3rd Edition, Prentice Hall, New Jersey 1997

Griliches, Zvi, "Estimating the Returns to Schooling: Some Econometric Problems ," Econometrica, January. 1977

Grossman, Michael, "The Human Capital Model of the Demand for Health," NBER Working Paper 7078, April 1999

Grossman, Michael, "The Correlation between Health and Schooling," in Household Production and Consumption, Ed N. E. Terleckyj, Studies in Income and Wealth, Vol. 40, Conference on Research in Income and Wealth. New York: Columbia University Press for the National Bureau of Economic Research, 1975

Grossman, Michael and R. Kaestner "Effects of Education on Health," in J.R. Berhman and N. Stacey Eds. The Social Benefits of education, University of Michigan Press, Ann Arbor, 1997 
Haines, Michael R. and Samuel H. Preston, "The Use of the Census to Estimate Childhood Mortality: Comparisons from the 1900 and 1910 United States Census Public Use Samples," Historical Methods, Vol 30, no.2, Spring 1997

Harmon, Colm, and Ian Walker, "Estimates of the Economic Return to Schooling for the United Kingdom," American Economic Review, Volume 85, Issue 5, December 1995

Hoek, H. W., A.S. Brown and E. Susser, "The Dutch Famine and Schizophrenia Spectrum Disorders," Social Psychiatry and Psychiatric Epidemiology, Volume 33, Issue 8, 1998

Katz, Michael, "A History of Compulsory Education Laws," Phi Delta Kappa Educational Foundation 1976

Kenkel, Donald, "Health Behavior, Health knowledge and Schooling," Journal of Political Economy, Volume 99, Issue 2, April 1991

Kitagawa, E.M. \& P.M. Hauser, Differential Mortality in the United States: A Study in Socioeconomic Epidemiology, Harvard University Press, 1973.

Landes William and Lewis C. Solomon, "Compulsory Schooling Legislation: An economic Analysis of Law and Social Change in the Nineteenth Century," Journal of Economic History, March 1972

Leigh, J. Paul and Rachna Dhir, "Schooling and Frailty Among Seniors," Economics of Education Review, Volume 16, No. 1, 1997

Lleras-Muney, Adriana, "Were State Laws on Compulsory Education Effective? An analysis from 1915 to 1939," Journal of Law and Economics, Vol. 45, No. 2, Part 1, forthcoming.

Lleras-Muney, Adriana and Frank Lichtenberg, "The effect of education on medical technology adoption: Are the more educated more likely to use new drugs?," mimeo, Princeton University, April 2002.

Maddala, G.S. Limited Dependent and Qualitative Variables in Econometrics, Econometric Society Monographs No. 3, Cambridge University Press, 1997

Meara, Ellen, "Why is Health Related to Socio-Economic Status? The Case of Pregnancy and Low Birth Weight," NBER Working Paper 8231, April 2001

Meghir, Costas and Marten Palme, "Assessing the Effect of Schooling on earnings Using a Social Experiment," Unpublished Working Paper, University College London, 1999

Menchik, Paul L., "Economic Status as a Determinant of Mortality among Black and White Older Men: Does Poverty Kill?," Population Studies, November 1993

Munasinghe, Lalith and Nachum Sicherman, "Why do Dancers Smoke? Time Preference, Occupational Choice, and Wage Growth," NBER Working Paper 7542, February 2000

Nelson, Richard R. and Edmund S. Phelps, "Investment in Humans, Technological Diffusion, and Economic Growth," American Economic Review, Volume 56, Issue1/2, March 1966

Newhouse, Joseph P., Free for All? Lessons from the Rand Health Insurance Experiment. Cambridge: Harvard University press. 1993

Perri, Timothy J., "Health Status and Schooling Decisions of Young Men," Economics of Education Review, 1984 
Rogers, Richard G., Robert A. Hummer and Charles B. Nam, Living and Dying in the USA, Academic Press 2000

Roseboom, T.J. et al, "Coronary heart Disease after Prenatal Exposure to the Dutch Famine, 1944-45," Heart, Volume 84, Issue 6, 2000

Rosenzweig M.R and T.P. Schultz, "Education and Household Production of Child Health," In Proceedings of the American Statistical Association (Social Statistics Section) Washington, DC: American Statistical Association, 1991

Rosenzweig, Mark R. and T. Paul Schultz "Schooling, Information and Nonmarket Productivity: Contraceptive Use and its effectiveness," International Economic Review, May 1989, 30920), pp. 457-77

Steven Ruggles and Matthew Sobek et. al., Integrated Public Use Microdata Series: Version 2.0 Minneapolis: Historical Census Projects, University of Minnesota, 1997

Sander, William, "Schooling and Quitting Smoking," Review of Economics and Statistics, 77,1995

Schmidt, Stefanie, "School Quality, Compulsory Education Laws, and the Growth of American High School Attendance, 1915-1935," MIT Ph.D. Dissertation 1996

Staiger, Douglas and James H. Stock, "Instrumental Variables Regression with Weak Instruments," Econometrica;65(3), May 1997

Starr, Paul, "The Social Transformation of American Medicine," New York: Basic Books, 1982

Strauss, John and Duncan Thomas, "Human Resources: Empirical Modelling of Household and Family Decisions," in Handbook of Development Economics, Vol. III, Edited by J. Behrman, T.N. Srinivasan. Elsevier Science 1995

Wolfe, Barbara and Jere R. Behrman, "Women's Schooling and Children's Health: Are the Effects Robust with Adult Sibling Control for the Women's Childhood Background?," Journal of Health Economics 6 , 1987

Woltz, Charles, K., "Compulsory Attendance at School," in Law and Contemporary Problems, School of Law, Duke University Vol. 20 Winter 1955 


\section{Appendix: Trends for Compulsory education and Child Labor laws}

\section{Compulsory Attendance Laws}

Age at which must enter school (enter age)

\begin{tabular}{cccc}
\hline & States 1915 & States 1928 & States 1939 \\
\hline 6 & 0 & 2 & 2 \\
7 & 16 & 28 & 33 \\
8 & 25 & 17 & 13 \\
9 & 1 & 1 & 0 \\
\hline Total & 42 & 48 & 48 \\
\hline
\end{tabular}

\section{Child Labor Laws}

Minimun age to get work permit (work age)

\begin{tabular}{cccc}
\hline & States 1915 & States 1928 & States 1939 \\
\hline 12 & 2 & & \\
13 & 1 & & \\
14 & 38 & 42 & 32 \\
15 & 4 & 4 & 4 \\
16 & 0 & 2 & 12 \\
\hline Total & 45 & 48 & 48 \\
\hline
\end{tabular}

\section{Continuation School Laws}

Have Continuation School Laws

\begin{tabular}{cccc}
\hline & States 1915 & States 1928 & States 1939 \\
\hline 0 & 36 & 20 & 19 \\
1 & 12 & 28 & 29 \\
\hline Total & 48 & 48 & 48
\end{tabular}

Constructed Variable: Implicit number of years had to attend school Childcom = work age - enter age

\begin{tabular}{cccc}
\hline & States 1915 & States 1928 & States 1939 \\
\hline 0 & 8 & & \\
4 & 1 & & \\
5 & 2 & 1 & \\
6 & 21 & 15 & 9 \\
7 & 14 & 26 & 23 \\
8 & 2 & 5 & 7 \\
9 & & & 8 \\
10 & & 1 & 1 \\
\hline Total & 48 & 48 & 48 \\
\hline
\end{tabular}



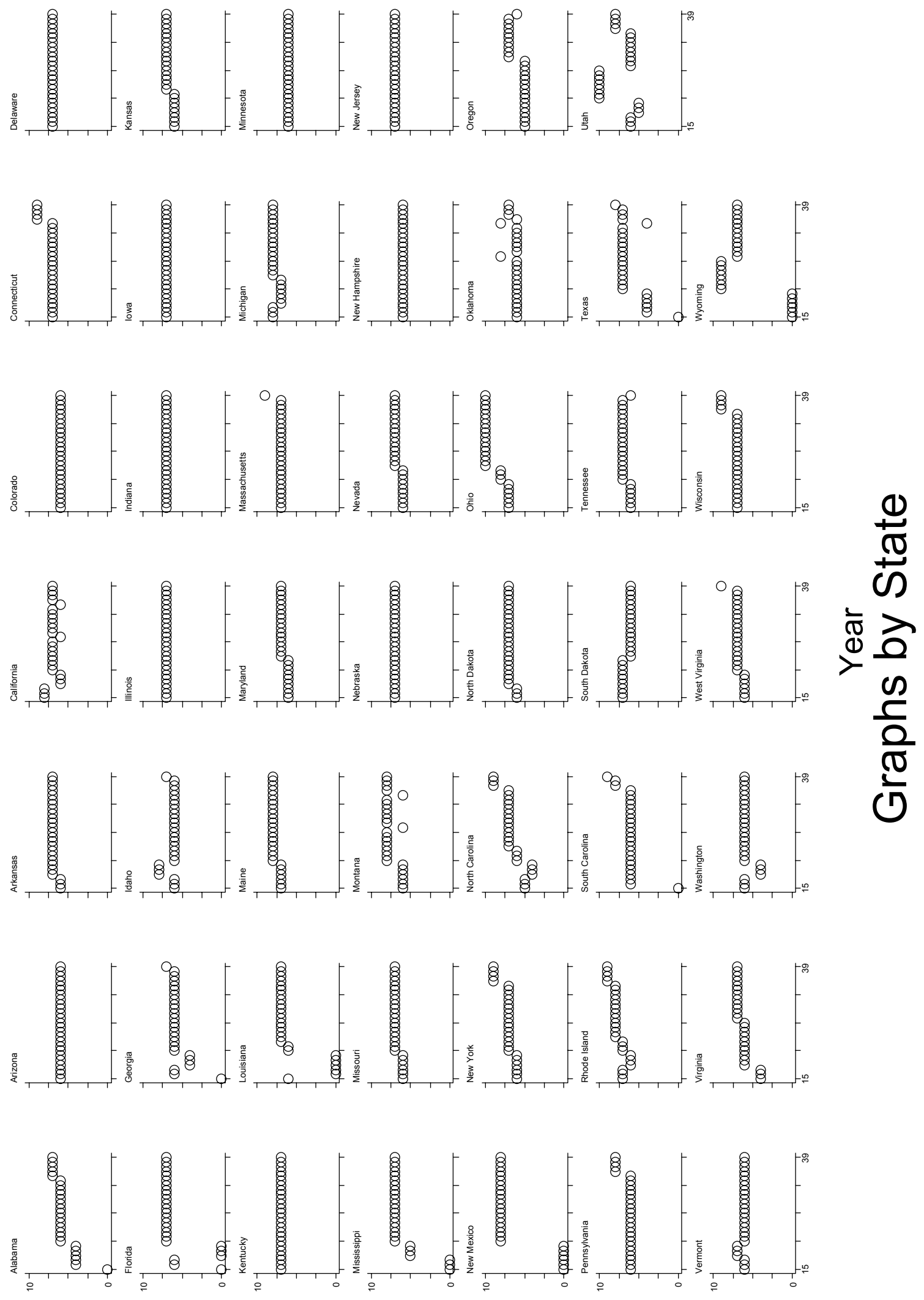

6u!jooyos Kıosjndmoo to sıeə入 
TABLE 1: SUMMARY STATISTICS

\begin{tabular}{|c|c|c|c|c|c|}
\hline \multirow{2}{*}{$\begin{array}{l} \\
\text { Variables }\end{array}$} & & \multicolumn{2}{|c|}{ Census* } & \multicolumn{2}{|c|}{ NEFS** } \\
\hline & & Mean & Std. Dev. & Mean & Std. Dev. \\
\hline Individual & 10 -year death rate & 0.106 & 0.136 & 0.254 & 0.435 \\
\hline \multirow{34}{*}{ characteristics } & Years of completed education & 10.697 & 1.020 & 10.360 & 3.326 \\
\hline & 1970 Dummy & 0.471 & 0.499 & & \\
\hline & Female & 0.517 & 0.500 & 0.540 & 0.498 \\
\hline & Married & 0.818 & 0.096 & 0.755 & 0.430 \\
\hline & Live in North & 0.255 & 0.369 & 0.214 & 0.410 \\
\hline & Live in West & 0.285 & 0.351 & 0.250 & 0.433 \\
\hline & Live in South & 0.159 & 0.227 & 0.269 & 0.444 \\
\hline & Live in an urban area & 0.685 & 0.122 & 0.526 & 0.499 \\
\hline & Age & 50.366 & 8.482 & 62.941 & 7.561 \\
\hline & Born in 1901 & 0.029 & 0.167 & 0.039 & 0.193 \\
\hline & Born in 1902 & 0.025 & 0.157 & 0.054 & 0.226 \\
\hline & Born in 1903 & 0.028 & 0.166 & 0.056 & 0.230 \\
\hline & Born in 1904 & 0.029 & 0.169 & 0.056 & 0.230 \\
\hline & Born in 1905 & 0.031 & 0.174 & 0.061 & 0.239 \\
\hline & Born in 1906 & 0.032 & 0.177 & 0.068 & 0.251 \\
\hline & Born in 1907 & 0.033 & 0.180 & 0.055 & 0.227 \\
\hline & Born in 1908 & 0.036 & 0.186 & 0.042 & 0.200 \\
\hline & Born in 1909 & 0.036 & 0.187 & 0.025 & 0.155 \\
\hline & Born in 1910 & 0.038 & 0.191 & 0.026 & 0.160 \\
\hline & Born in 1911 & 0.039 & 0.193 & 0.027 & 0.161 \\
\hline & Born in 1912 & 0.040 & 0.195 & 0.028 & 0.165 \\
\hline & Born in 1913 & 0.042 & 0.200 & 0.028 & 0.165 \\
\hline & Born in 1914 & 0.043 & 0.202 & 0.031 & 0.174 \\
\hline & Born in 1915 & 0.044 & 0.205 & 0.033 & 0.178 \\
\hline & Born in 1916 & 0.044 & 0.205 & 0.032 & 0.177 \\
\hline & Born in 1917 & 0.044 & 0.206 & 0.034 & 0.182 \\
\hline & Born in 1918 & 0.046 & 0.209 & 0.035 & 0.184 \\
\hline & Born in 1919 & 0.047 & 0.213 & 0.041 & 0.198 \\
\hline & Born in 1920 & 0.048 & 0.213 & 0.037 & 0.188 \\
\hline & Born in 1921 & 0.048 & 0.214 & 0.038 & 0.192 \\
\hline & Born in 1922 & 0.050 & 0.217 & 0.039 & 0.194 \\
\hline & Born in 1923 & 0.049 & 0.216 & 0.034 & 0.182 \\
\hline & Born in 1924 & 0.049 & 0.215 & 0.044 & 0.206 \\
\hline & Born in 1925 & 0.050 & 0.217 & 0.036 & 0.187 \\
\hline & $\%$ Urban & 53.523 & 21.279 & 49.846 & 20.734 \\
\hline \multirow[t]{8}{*}{ Characteristics } & $\%$ Foreign & 11.737 & 8.523 & 11.489 & 8.434 \\
\hline & $\%$ Black & 8.983 & 11.901 & 10.108 & 13.652 \\
\hline & $\%$ Employed in manufacturing & 0.067 & 0.039 & 0.065 & 0.040 \\
\hline & Annual Manufacturing wage & 7161.911 & 1368.253 & 6971.696 & 1380.099 \\
\hline & Value of farm per acre & 540.048 & 276.353 & 549.371 & 292.371 \\
\hline & Per capita number of doctors & 0.001 & 0.000 & 0.0013 & 0.0003 \\
\hline & Per capita education expenditures & 96.474 & 42.142 & 86.305 & 44.411 \\
\hline & Number of school buildings per sq. mile & 0.174 & 0.090 & 0.173 & 0.092 \\
\hline
\end{tabular}

$* \mathrm{~N}=4795$, corresponding to cells defined at the gender, state-of-birth, and cohort. All means calculated using weights, where the weights are given by the number of observations in each cell. Monetary values are in 1982-84 dollars. ${ }^{* *} \mathrm{~N}$ : 4554 . Monetary values are in 1982-84 dollars 

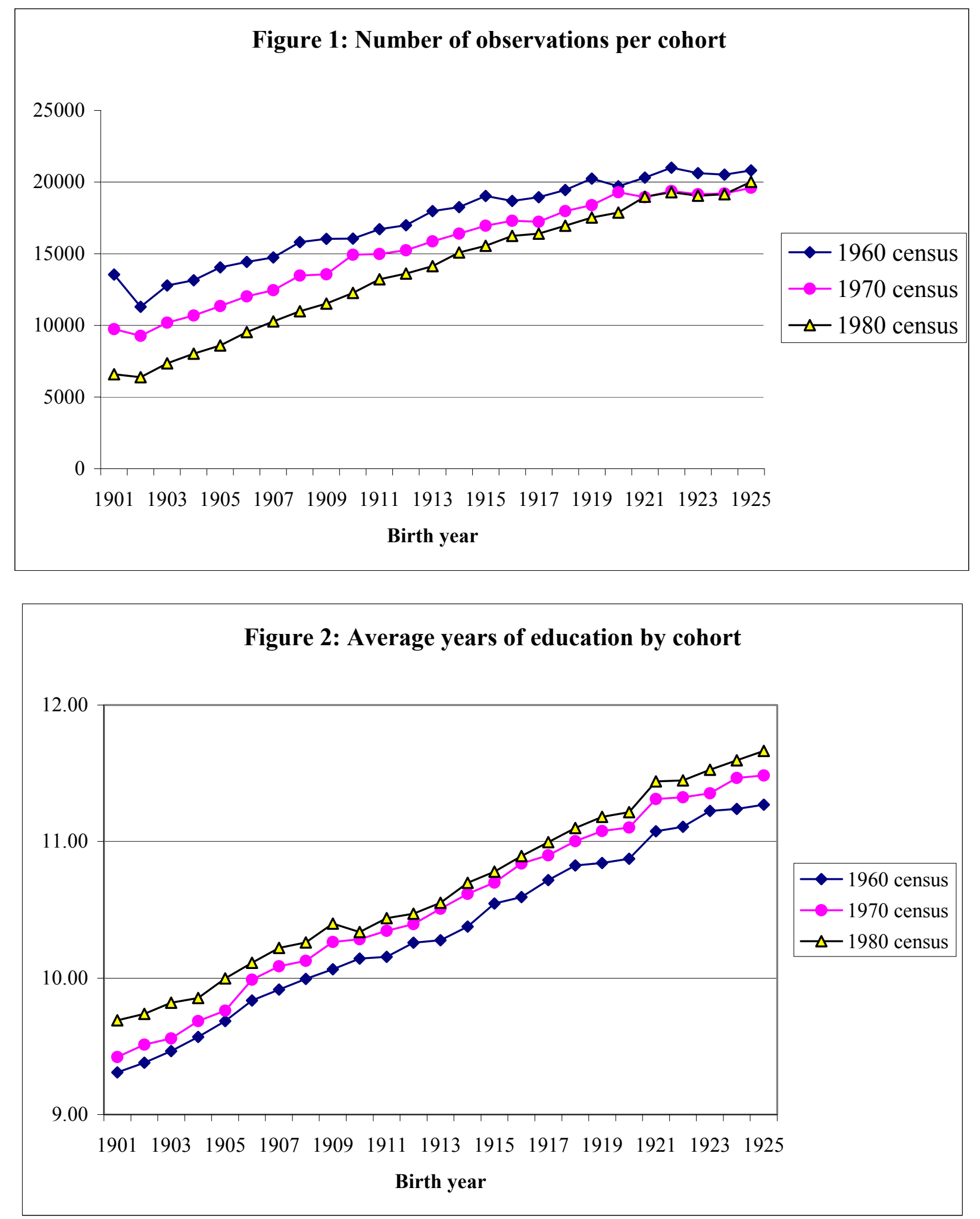

Note: Figures 1 and 2 follow the same cohorts from the 1960 census up to the 1980 census.

In Figure 1 we can observe that that 10-year mortality increases with age: for older cohorts the number of individuals observed in 1980 is much smaller than in 1960 or 1970.

In figure 2 we can see that the average level of education is higher in 1980 than in 1960 for all cohorts, suggesting that those who died in each cohort had bellow average levels of education. 


\section{Figure 3: Calculating Death Rates with the Census}

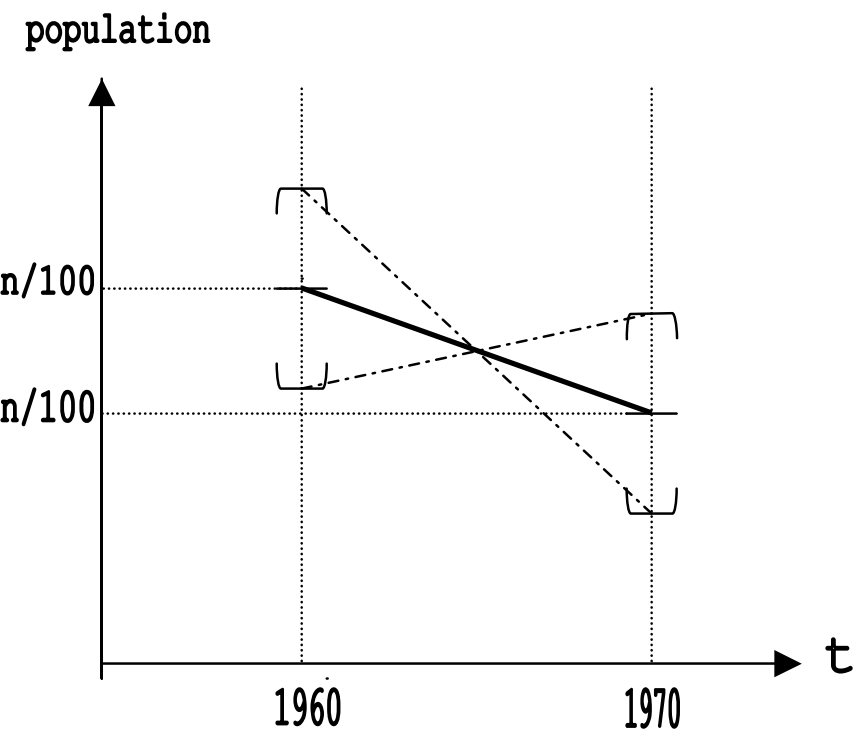

The 1960 and 1970 census are 1/100 random samples of the population, therefore the number of individuals in any given group is always observed with error. Because of this sampling error the death rates for any given group are overestimated $50 \%$ of the time and underestimated $50 \%$ of the time. However, since the sampling is truly random, the observed death rates are consistent estimates of the true death rates.

\section{Figure 3B: An example for a young cohort: 0 death rate}

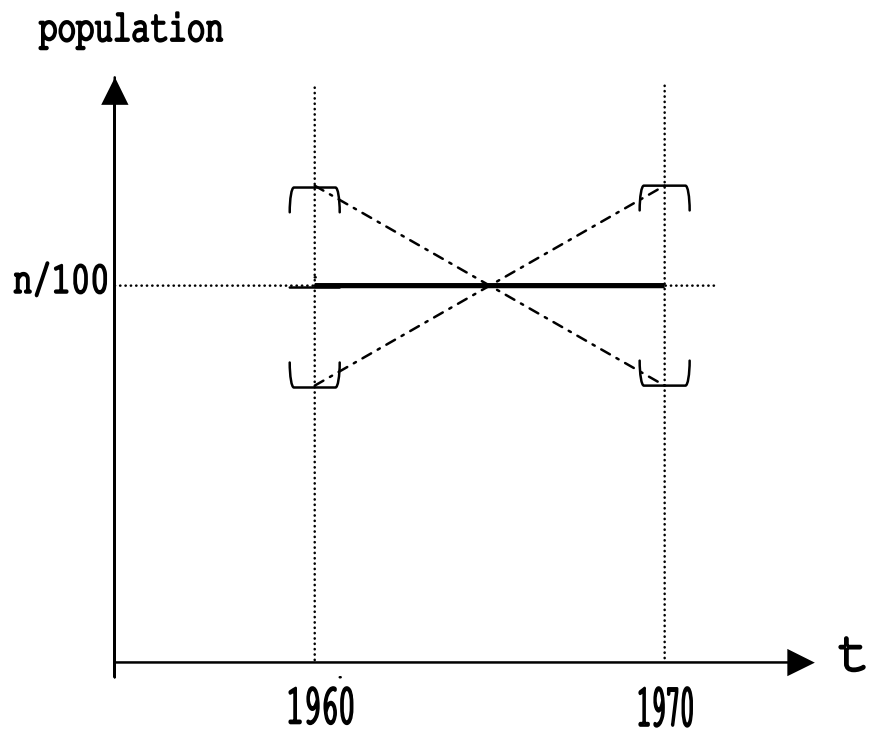

If the true death rate is 0 then I observe $50 \%$ negative death rates. As cohorts age, the death rate increases (see example above) the number of negative death rates falls. 


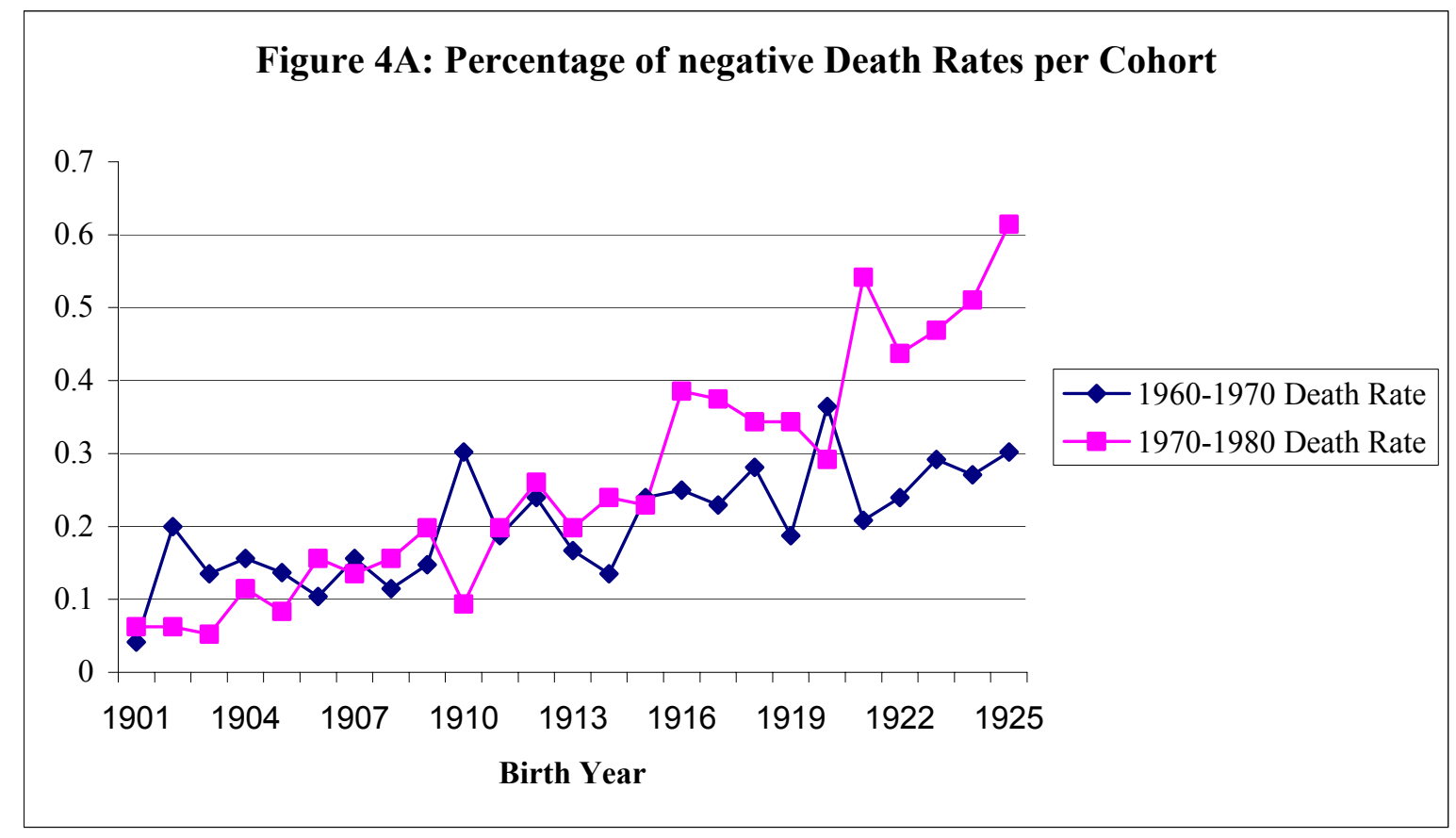

Figure 4B: Percentage of negative death rates by average state size

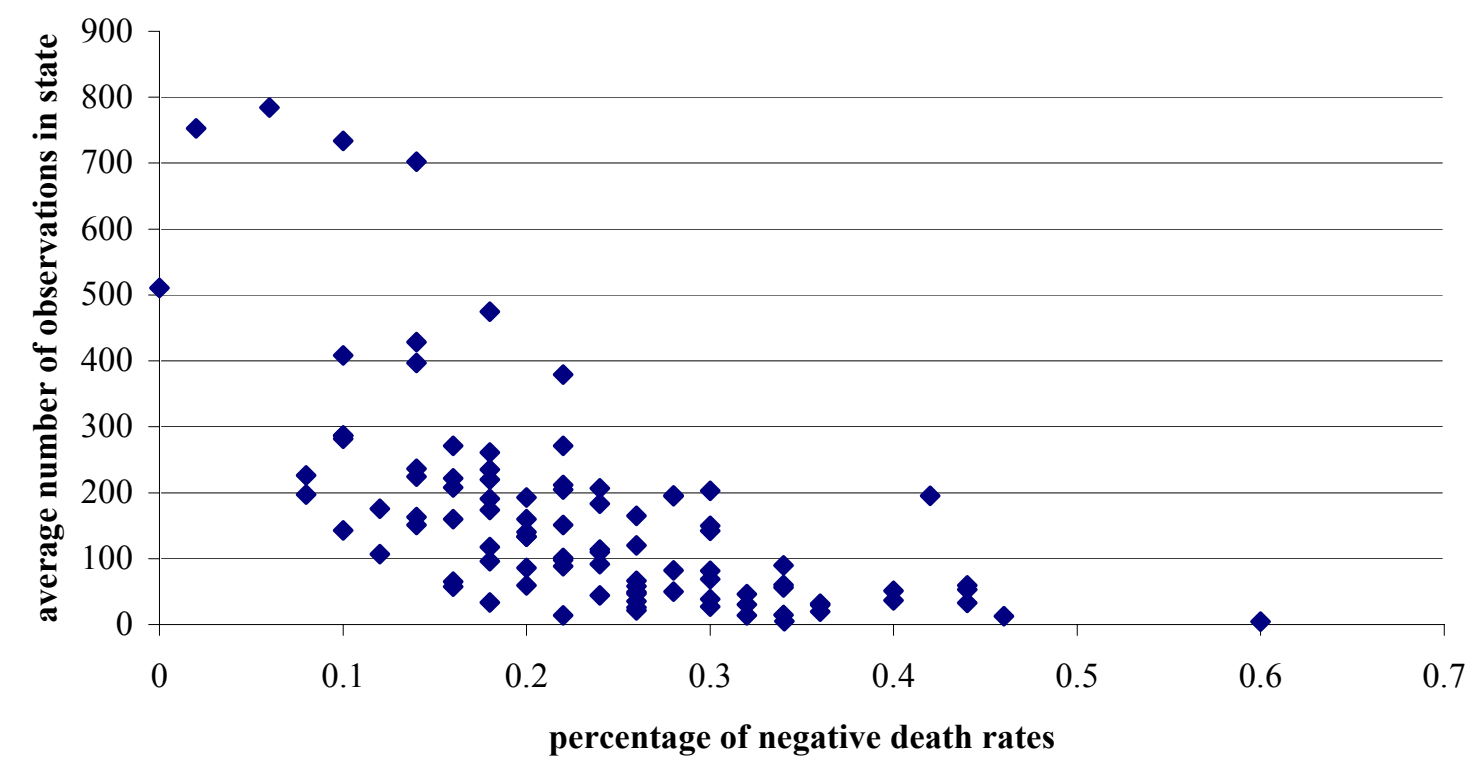




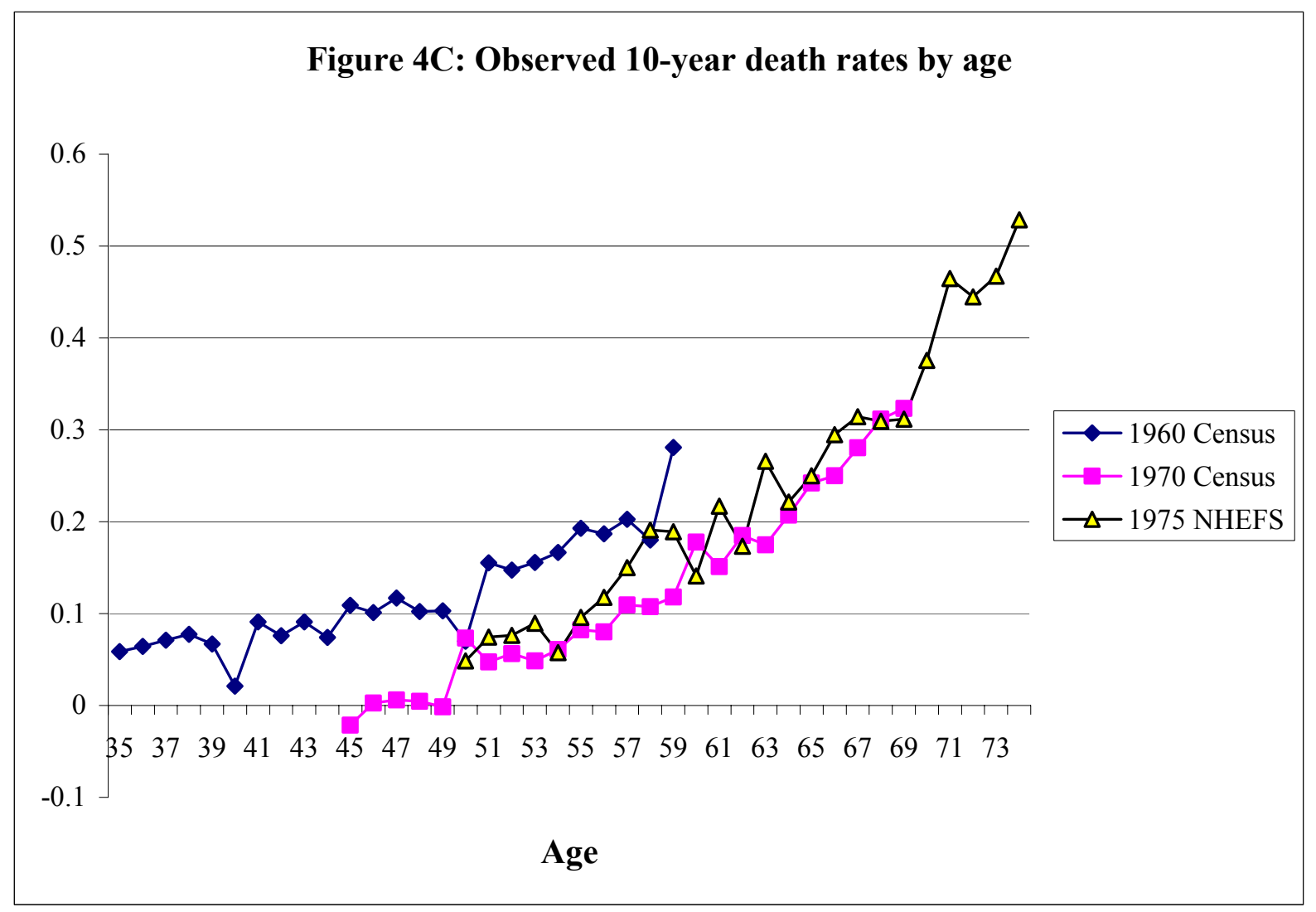



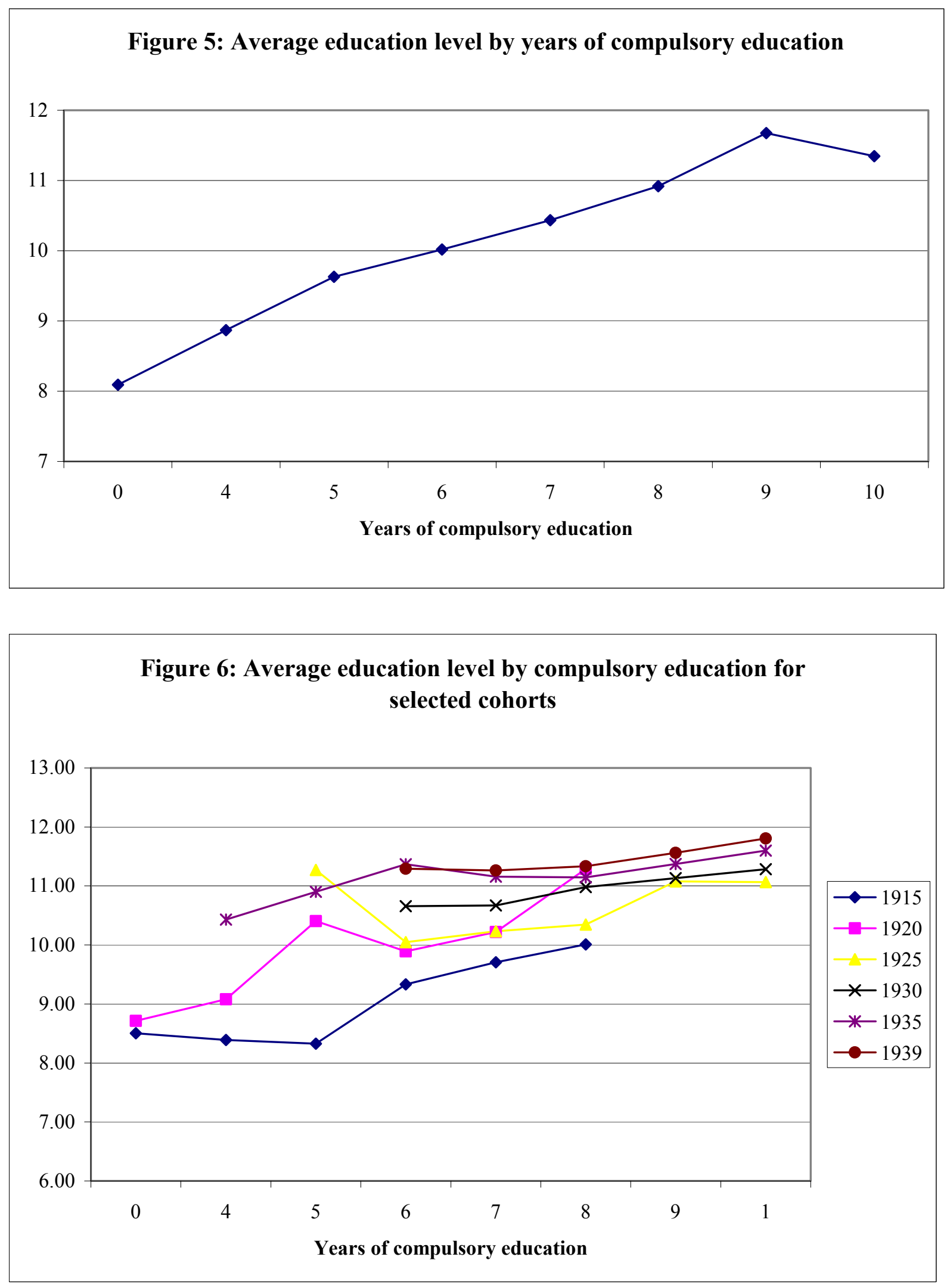
TABLE 2: EFFECT OF COMPULSORY EDUCATION LAWS ON EDUCATION

\begin{tabular}{|c|c|c|c|c|}
\hline Variables & & Individual data & Individual data & Aggregate data \\
\hline$\overline{\text { Dependent Variable }}$ & Education & & & \\
\hline Education Laws & Childcom Category 4 & $0.347^{* *}$ & $0.355^{* *}$ & $0.323^{* *}$ \\
\hline & & $(0.075)$ & $(0.088)$ & $(0.077)$ \\
\hline & Childcom Category 5 & $0.323 * *$ & $0.260 * *$ & $0.321^{* *}$ \\
\hline & & $(0.090)$ & $(0.099)$ & $(0.098)$ \\
\hline & Childcom Category 6 & $0.274 * *$ & $0.302 * *$ & $0.266^{* *}$ \\
\hline & & $(0.069)$ & $(0.087)$ & $(.074)$ \\
\hline & Childcom Category 7 & $0.385 * *$ & $0.408^{* *}$ & $0.369^{* *}$ \\
\hline & & $(0.070)$ & $(0.087)$ & $(0.074)$ \\
\hline & Childcom Category 8 & $0.416^{* *}$ & $0.398 * *$ & $0.315^{* *}$ \\
\hline & & $(0.075)$ & $(0.089)$ & $(0.078)$ \\
\hline & Childcom Category 9 & $0.580 * *$ & $0.512 * *$ & $0.470^{* *}$ \\
\hline & & $(0.076)$ & $(0.092)$ & $(0.084)$ \\
\hline & Childcom Category 10 & $0.325^{* *}$ & $0.328 * *$ & $0.318^{* *}$ \\
\hline & & $(0.080)$ & $(0.095)$ & $(0.095)$ \\
\hline & Continuation School Required $(=1)$ & 0.027 & 0.017 & 0.027 \\
\hline & & $(0.026)$ & $(0.028)$ & $(0.031)$ \\
\hline Individual & Female & $0.116^{* *}$ & $0.140^{* *}$ & -0.012 \\
\hline characteristics & & $(0.014)$ & $(0.014)$ & $(0.014)$ \\
\hline & Married & & $0.433 * *$ & $-1.111 * *$ \\
\hline & & & $(0.011)$ & $(0.097)$ \\
\hline & Live in an urban area & & $0.968 * *$ & $0.278 * *$ \\
\hline & & & $(0.019)$ & $(0.138)$ \\
\hline State-of-Birth & $\%$ Urban & & $0.021 * *$ & $0.028 * *$ \\
\hline Characteristics & & & $(0.004)$ & $(0.005)$ \\
\hline & $\%$ Foreign & & -0.002 & 0.004 \\
\hline & & & $(0.008)$ & $(0.010)$ \\
\hline & $\%$ Black & & $0.024 * *$ & $0.020^{* *}$ \\
\hline & & & $(0.009)$ & $(0.010)$ \\
\hline & $\%$ Employed in manufacturing & & -0.350 & $-1.220 * *$ \\
\hline & & & $(0.513)$ & $(0.621)$ \\
\hline & Annual Manufacturing wage & & 0.000 & 0.000 \\
\hline & & & $(0.000)$ & $(0.000)$ \\
\hline & Value of farm per acre & & 0.000 & 0.000 \\
\hline & & & $(0.000)$ & $(0.000)$ \\
\hline & Per capita number of doctors & & $150.018 * *$ & $188.615 * *$ \\
\hline & & & $(71.840)$ & $(66.2)$ \\
\hline & Per capita education expenditures & & $0.001 * *$ & 0.000 \\
\hline & & & $(0.000)$ & $(0.000)$ \\
\hline & Number of school buildings per sq. mile & & -0.359 & -0.166 \\
\hline & & & $(0.289)$ & $(0.373)$ \\
\hline & 3 region of residence dummies & No & Yes & Yes \\
\hline & Region of birth*cohort dummies & No & Yes & Yes \\
\hline & R-Squared & 0.0811 & 0.1052 & 0.888 \\
\hline & F-statistic on instruments & $14.93^{* *}$ & $8.37 * *$ & $4.49 * *$ \\
\hline & Partial R-squared & 0.0003 & 0.0001 & 0.0108 \\
\hline
\end{tabular}

* significant at $10 \% * *$ significant at 5\%. All regressions include a dummy for the 1970 census, stateof-birth dummies, cohort dummies and an intercept. For the individual-level regressions (1 and 2) $\mathrm{N}=814805$ and the standard errors (in parenthesis) are clustered at the state-of-birth and cohort level.

(a) Childcom=work permit age - entry age. Childcom $=0$ is the excluded category.

(b) Data aggregated by gender/cohort/state-of-birth. Robust standard errors. $\mathrm{N}=4792$ 
TABLE 3: EFFECT OF EDUCATION ON MORTALITY-LEAST SQUARE RESULTS

\begin{tabular}{|c|c|c|c|c|c|c|}
\hline es & & & & & & \\
\hline Data & & Census & NHEFS & NHEFS & NHEFS & NHEFS \\
\hline Method & & WLS & OLS & Probit $^{(a)}$ & WLS & W LS \\
\hline Level $^{(\mathrm{d})}$ & & Aggregate $^{(\mathrm{b})}$ & Individual & Individual & Aggregate $^{(b)}$ & Aggregate $^{(\mathrm{c})}$ \\
\hline $\begin{array}{l}\text { Dependent } \\
\text { Variable }\end{array}$ & & $\begin{array}{l}\text { 10-year } \\
\text { death rate }\end{array}$ & $\begin{array}{c}\text { died } \\
75-85\end{array}$ & $\begin{array}{c}\text { died } \\
75-85\end{array}$ & $\begin{array}{c}\text { death rate } \\
75-85\end{array}$ & $\begin{array}{c}\text { death rate } \\
75-85\end{array}$ \\
\hline $\begin{array}{l}\text { Individual } \\
\text { characteristics }\end{array}$ & $\begin{array}{l}\text { Education } \\
\text { Female } \\
\text { Married } \\
\text { Live in an urban area }\end{array}$ & $\begin{array}{c}-0.012 * * \\
(0.004) \\
-0.048^{* *} \\
(0.004) \\
0.227^{* *} \\
(0.030) \\
-0.136 * * \\
(0.044)\end{array}$ & $\begin{array}{c}-0.012 * * \\
(0.002) \\
-0.147 * * \\
(0.013) \\
-0.044 * * \\
(0.016) \\
0.037 * * \\
(0.015)\end{array}$ & $\begin{array}{c}-0.011 * * \\
(0.002) \\
-0.151^{* *} \\
(0.013) \\
-0.053 \\
(0.015) \\
0.039 * * \\
(0.015)\end{array}$ & $\begin{array}{c}-0.017^{* *} \\
(0.004) \\
-0.137^{* *} \\
(0.015) \\
-0.005 \\
(0.030) \\
0.056^{* *} \\
(0.024)\end{array}$ & $\begin{array}{c}-0.013 * * \\
(0.005) \\
-0.139 * * \\
(0.030) \\
-0.015 \\
(0.037) \\
0.080 * * \\
(0.030)\end{array}$ \\
\hline $\begin{array}{l}\text { State-of-Birth } \\
\text { Characteristics }\end{array}$ & $\begin{array}{l}\% \text { Urban } \\
\% \text { Foreign } \\
\% \text { Black } \\
\% \text { Employed in manufacturing } \\
\text { Annual Manufacturing wage } \\
\text { Value of farm per acre } \\
\text { Per capita number of doctors } \\
\text { Per capita education expenditures } \\
\text { \# of school buildings per sq. mile }\end{array}$ & $\begin{array}{c}0.000 \\
(0.001) \\
0.000 \\
(0.002) \\
0.000 \\
(0.002) \\
-0.075 \\
(0.105) \\
0.000 \\
(0.000) \\
0.000 \\
(0.000) \\
-2.043 \\
(14.384) \\
0.000 \\
(0.000) \\
0.045 \\
(0.064)\end{array}$ & $\begin{array}{c}-0.003 \\
(0.005) \\
0.005 \\
(0.007) \\
-0.014 * \\
(0.008) \\
-0.085 \\
(0.590) \\
0.000 \\
(0.000) \\
0.000 \\
(0.000) \\
1.058 \\
(48.228) \\
0.000 \\
(0.000) \\
0.712 * * \\
(0.345)\end{array}$ & $\begin{array}{c}-0.003 \\
(0.005) \\
0.012 \\
(0.008) \\
-0.012 \\
(0.008) \\
-0.060 \\
(0.563) \\
0.000 \\
(0.000) \\
0.000 \\
(0.000) \\
17.451 \\
(39.746) \\
0.000 \\
(0.000) \\
0.744 * * \\
(0.334)\end{array}$ & $\begin{array}{c}-0.002 \\
(0.005) \\
0.005 \\
(0.007) \\
-0.014 \\
(0.009) \\
-0.091 \\
(0.621) \\
0.000 \\
(0.000) \\
0.000 \\
(0.000) \\
-0.762 \\
(49.833) \\
0.000 \\
(0.000) \\
0.725^{* *} \\
(0.360)\end{array}$ & $\begin{array}{c}-0.002 \\
(0.005) \\
0.005 \\
(0.007) \\
-0.014 \\
(0.009) \\
-0.100 \\
(0.640) \\
0.000 \\
(0.000) \\
0.000 \\
(0.000) \\
-2.139 \\
(52.857) \\
0.000 \\
(0.000) \\
0.758^{* *} \\
(0.380)\end{array}$ \\
\hline & $\begin{array}{l}\mathrm{N} \\
\text { R-Squared }\end{array}$ & $\begin{array}{c}4792 \\
0.3685\end{array}$ & $\begin{array}{c}4554 \\
0.1736\end{array}$ & 4554 & $\begin{array}{c}1557 \\
0.3952\end{array}$ & $\begin{array}{c}942 \\
0.5219\end{array}$ \\
\hline
\end{tabular}

All regressions include 24 cohort dummies, 47 state of birth dummies, region-of-birth * cohort, region of residence dummies and an intercept. Standard errors (in parenthesis) are clustered at the state-of-birth and cohort level. The census regressions also include a dummy for the 1970 census.

(a) The reported coefficients are the mean marginal effects. The standard errors are calculated using the Delta Method.

(b) Data are aggregated at the cohort/gender and state-of-birth level.

(c) Data aggregated at the cohort and state-of-birth level only.

(d) All regressions at the aggregate level are weighted by the number of observations in the original cell

* significant at $10 \% * *$ significant at $5 \%$. 
TABLE 4: EFFECT OF EDUCATION ON MORTALITY-IV RESULTS

\begin{tabular}{|c|c|c|c|c|c|}
\hline \multicolumn{6}{|l|}{ Variables } \\
\hline Data & & NHEFS $^{(b)}$ & Census $^{(\mathrm{a})(\mathrm{c})}$ & Census $^{(\mathrm{a})(\mathrm{b})(\mathrm{c})}$ & Census $^{(a)(b)(c)}$ \\
\hline Method & & 2SLS & Wald & 2SLS & Mixed 2SLS \\
\hline Level & & Individual & Aggregate & Aggregate & Aggregate \\
\hline $\begin{array}{l}\text { Dependent } \\
\text { Variable }\end{array}$ & & $\begin{array}{c}\text { Died } \\
1975-1985\end{array}$ & $\begin{array}{c}\text { 10-year } \\
\text { death rate }\end{array}$ & $\begin{array}{c}\text { 10-year } \\
\text { death rate }\end{array}$ & $\begin{array}{c}\text { 10-year } \\
\text { death rate }\end{array}$ \\
\hline \multirow[t]{5}{*}{$\begin{array}{l}\text { Individual } \\
\text { characteristics }\end{array}$} & Education & $\begin{array}{l}-0.020 \\
(0.054)\end{array}$ & $\begin{array}{c}-0.037 * * \\
(0.006)\end{array}$ & $\begin{array}{l}-0.045^{*} \\
(0.026)\end{array}$ & $\begin{array}{c}-0.059 * * \\
(0.027)\end{array}$ \\
\hline & 1970 Dummy & & $\begin{array}{c}0.003 \\
(0.004)\end{array}$ & $\begin{array}{c}0.012 * * \\
(0.005)\end{array}$ & $\begin{array}{l}0.021 * * \\
(0.007)\end{array}$ \\
\hline & Female & $\begin{array}{c}-0.142 * * \\
(0.030)\end{array}$ & $\begin{array}{c}-0.071 * * \\
(0.004)\end{array}$ & $\begin{array}{c}-0.048^{* *} \\
(0.004)\end{array}$ & $\begin{array}{c}-0.040^{* *} \\
(0.005)\end{array}$ \\
\hline & Married & $\begin{array}{l}-0.040 \\
(0.027)\end{array}$ & & $\begin{array}{c}0.190^{* *} \\
(0.041)\end{array}$ & $\begin{array}{l}0.266^{* *} \\
(0.031)\end{array}$ \\
\hline & Live in an urban area & $\begin{array}{c}0.046 \\
(0.055)\end{array}$ & & $\begin{array}{l}-0.126^{* *} \\
(0.045)\end{array}$ & $\begin{array}{l}-0.080 \\
(0.054)\end{array}$ \\
\hline \multirow{16}{*}{$\begin{array}{l}\text { State-of-Birth } \\
\text { Characteristics }\end{array}$} & $\%$ Urban & -0.002 & & 0.001 & 0.001 \\
\hline & & $(0.005)$ & & $(0.001)$ & $(0.001)$ \\
\hline & $\%$ Foreign & $\begin{array}{c}0.005 \\
(0.007)\end{array}$ & & $\begin{array}{c}0.001 \\
(0.002)\end{array}$ & $\begin{array}{c}0.001 \\
(0.002)\end{array}$ \\
\hline & $\%$ Black & $\begin{array}{l}-0.014 \\
(0.008)\end{array}$ & & $\begin{array}{c}0.001 \\
(0.002)\end{array}$ & $\begin{array}{c}0.001 \\
(0.002)\end{array}$ \\
\hline & \% Employed in manufacturing & $\begin{array}{l}-0.089 \\
(0.605)\end{array}$ & & $\begin{array}{l}-0.118 \\
(0.113)\end{array}$ & $\begin{array}{l}-0.080 \\
(0.137)\end{array}$ \\
\hline & Annual Manufacturing wage & $\begin{array}{c}0.000 \\
(0.000)\end{array}$ & & $\begin{array}{c}0.000 \\
(0.000)\end{array}$ & $\begin{array}{c}0.000 \\
(0.000)\end{array}$ \\
\hline & Value of farm per acre & $\begin{array}{c}0.000 \\
(0.000)\end{array}$ & & $\begin{array}{c}0.000 \\
(0.000)\end{array}$ & $\begin{array}{c}0.000 \\
(0.000)\end{array}$ \\
\hline & Per capita number of doctors & $\begin{array}{c}7.298 \\
(62.347)\end{array}$ & & $\begin{array}{c}6.078 \\
(15.337)\end{array}$ & $\begin{array}{c}6.675 \\
(17.31)\end{array}$ \\
\hline & Per capita education expenditures & $\begin{array}{c}0.000 \\
(0.000)\end{array}$ & & $\begin{array}{c}0.000 \\
(0.000)\end{array}$ & $\begin{array}{c}0.000 \\
(0.000)\end{array}$ \\
\hline & Number of school buildings per sq. mile & $\begin{array}{l}0.698^{* *} \\
(0.350)\end{array}$ & & $\begin{array}{c}0.051 \\
(0.066)\end{array}$ & $\begin{array}{c}0.044 \\
(0.075)\end{array}$ \\
\hline & State-of-birth Dummies & Yes & No & Yes & Yes \\
\hline & Region of Birth Dummies & No & Yes & No & No \\
\hline & Cohort Dummies & Yes & Yes & Yes & Yes \\
\hline & Region-of-birth*cohort & Yes & No & Yes & Yes \\
\hline & Region of residence dummies & Yes & No & Yes & Yes \\
\hline & $\mathrm{N}$ & 4554 & 1396 & 4792 & 4792 \\
\hline
\end{tabular}

All regressions include an intercept.

(a) Regressions are weighted by the number of observations in the original cell.

(b) Standard errors (in parenthesis) are clustered at the state-of-birth and cohort level and have been corrected in the second stage.

(c) Note: P2SLS and aggregate 2SLS use data aggregated at the gender/cohort/state-of-birth. Wald uses data aggregated at the gender/cohort/region-of-birth/compulsory education laws level.

* significant at $10 \% * *$ significant at $5 \%$. 
TABLE 5: ADDITIONAL ESTIMATIONS

A: Effect of education on mortality:

Quarter of birth, laws and interactions used as instruments

\begin{tabular}{llll}
\hline \hline & & 2SLS & Mixed 2SLS \\
\hline $\begin{array}{l}\text { Dependent } \\
\text { Variable }\end{array}$ & 10 -year death rate & & \\
& & & \\
\hline Individual & Education & $-.067^{* *}$ & $-.062^{* *}$ \\
& & $(.0260)$ & $(.024)$ \\
\hline
\end{tabular}

B: Effect of compulsory schooling on education:

Reduced form Results (OLS)

Dependent 10-year death rate

Variable

\begin{tabular}{ll} 
Childcom & $-0.0027^{* *}$ \\
& $(0.0013)$ \\
Continuation school & -0.0032 \\
& $(0.005)$ \\
\hline
\end{tabular}

C: Effect of education on mortality: Results corrected for Age Heaping: (Exclude ages 40, 50, and 60)

\begin{tabular}{llll}
\hline \hline & & 2SLS & Mixed 2SLS \\
\hline $\begin{array}{l}\text { Dependent } \\
\text { Variable }\end{array}$ & 10 -year death rate & & \\
& & & \\
\hline Individual & Education & -.040 & -.052 \\
& & $(.026)$ & $(.026)$ \\
\hline
\end{tabular}

D: Effect of education on mortality:

Results by region of birth

\begin{tabular}{|c|c|c|}
\hline $\begin{array}{l}\text { Dependent Variable10- } \\
\text { year death rate }\end{array}$ & 2 2SLS & "Mixed 2SLS \\
\hline North & $\begin{array}{l}-0.047 \\
(0.060)\end{array}$ & $\begin{array}{l}-0.083 \\
(0.108)\end{array}$ \\
\hline South & $\begin{array}{l}-0.044 \\
(0.038)\end{array}$ & $\begin{array}{l}-0.061 * \\
(0.033)\end{array}$ \\
\hline West & $\begin{array}{l}-0.078 \\
(0.071)\end{array}$ & $\begin{array}{l}-0.071 \\
(0.095)\end{array}$ \\
\hline Midwest & $\begin{array}{l}-0.045 \\
(0.043)\end{array}$ & $\begin{array}{l}-0.014 \\
(0.095)\end{array}$ \\
\hline
\end{tabular}

* significant at $10 \% * *$ significant at $5 \%$. 
TABLE 6: EFFECT OF EDUCATION ON MORTALITY-IV RESULTS BY GENDER

\begin{tabular}{|c|c|c|c|c|c|}
\hline \multirow{2}{*}{$\begin{array}{l}\text { Variables } \\
\end{array}$} & & \multirow{2}{*}{$\begin{array}{l}\text { 2SLS } \\
\text { Males }\end{array}$} & \multirow{2}{*}{$\begin{array}{c}\text { 2SLS } \\
\text { Females }\end{array}$} & \multirow{2}{*}{$\begin{array}{c}\text { Mixed 2SLS } \\
\text { Males }\end{array}$} & \multirow{2}{*}{$\begin{array}{c}\text { Mixed 2SLS } \\
\text { Females }\end{array}$} \\
\hline & & & & & \\
\hline $\begin{array}{l}\text { Dependent } \\
\text { Variable }\end{array}$ & 10-year death rate & & & & \\
\hline \multirow[t]{4}{*}{$\begin{array}{l}\text { Individual } \\
\text { characteristics }\end{array}$} & Education & $\begin{array}{l}-0.047 \\
(0.051)\end{array}$ & $\begin{array}{l}-0.044 \\
(0.063)\end{array}$ & $\begin{array}{l}-0.077 \\
(0.040)\end{array}$ & $\begin{array}{l}-0.054 \\
(0.039)\end{array}$ \\
\hline & Married & $\begin{array}{c}-0.292 * * \\
(0.082)\end{array}$ & $\begin{array}{c}-0.311 * * \\
(0.059)\end{array}$ & $\begin{array}{c}-0.263 * * \\
(0.087)\end{array}$ & $\begin{array}{c}-0.297 * * \\
(0.065)\end{array}$ \\
\hline & Dummy for 1970 & $\begin{array}{c}0.025 \\
(0.009)\end{array}$ & $\begin{array}{c}-0.057 * * \\
(0.011)\end{array}$ & $\begin{array}{l}0.032 * * \\
(0.009)\end{array}$ & $\begin{array}{c}-0.052 * * \\
(0.011)\end{array}$ \\
\hline & Live in an urban area & $\begin{array}{l}-0.096 \\
(0.059)\end{array}$ & $\begin{array}{l}-0.102 \\
(0.067)\end{array}$ & $\begin{array}{l}-0.002 \\
(0.079)\end{array}$ & $\begin{array}{l}-0.036 \\
(0.078)\end{array}$ \\
\hline \multirow{10}{*}{$\begin{array}{l}\text { State-of-Birth } \\
\text { Characteristics }\end{array}$} & $\%$ Urban & 0.002 & 0.001 & 0.001 & 0.001 \\
\hline & & $(0.003)$ & $(0.002)$ & $(0.002)$ & $(0.002)$ \\
\hline & $\%$ Foreign & $\begin{array}{l}-0.001 \\
(0.004)\end{array}$ & $\begin{array}{c}0.001 \\
(0.004)\end{array}$ & $\begin{array}{l}-0.001 \\
(0.003)\end{array}$ & $\begin{array}{c}0.001 \\
(0.003)\end{array}$ \\
\hline & $\%$ Black & $\begin{array}{c}0.000 \\
(0.004)\end{array}$ & $\begin{array}{l}-0.001 \\
(0.004)\end{array}$ & $\begin{array}{c}0.000 \\
(0.003)\end{array}$ & $\begin{array}{l}-0.001 \\
(0.003)\end{array}$ \\
\hline & $\%$ Employed in manufacturing & $\begin{array}{l}-0.095 \\
(0.328)\end{array}$ & $\begin{array}{l}-0.128 \\
(0.264)\end{array}$ & $\begin{array}{l}-0.056 \\
(0.182)\end{array}$ & $\begin{array}{l}-0.103 \\
(0.194)\end{array}$ \\
\hline & Annual Manufacturing wage & $\begin{array}{c}0.000 \\
(0.000)\end{array}$ & $\begin{array}{c}0.000 \\
(0.000)\end{array}$ & $\begin{array}{c}0.000 \\
(0.000)\end{array}$ & $\begin{array}{c}0.000 \\
(0.000)\end{array}$ \\
\hline & Value of farm per acre & $\begin{array}{c}0.000 \\
(0.000)\end{array}$ & $\begin{array}{c}0.000 \\
(0.000)\end{array}$ & $\begin{array}{c}0.000 \\
(0.000)\end{array}$ & $\begin{array}{c}0.000 \\
(0.000)\end{array}$ \\
\hline & Per capita number of doctors & $\begin{array}{c}22.270 \\
(24.002)\end{array}$ & $\begin{array}{c}-6.219 \\
(32.441)\end{array}$ & $\begin{array}{c}27.940 \\
(22.782)\end{array}$ & $\begin{array}{l}-5.860 \\
(26.29)\end{array}$ \\
\hline & Per capita education expenditures & $\begin{array}{c}0.000 \\
(0.000)\end{array}$ & $\begin{array}{c}0.000 \\
(0.000)\end{array}$ & $\begin{array}{c}0.000 \\
(0.000)\end{array}$ & $\begin{array}{c}0.000 \\
(0.000)\end{array}$ \\
\hline & Number of school buildings per sq. mile & $\begin{array}{l}-0.018 \\
(0.148)\end{array}$ & $\begin{array}{c}0.078 \\
(0.155)\end{array}$ & $\begin{array}{l}-0.057 \\
(0.103)\end{array}$ & $\begin{array}{c}0.094 \\
(0.106)\end{array}$ \\
\hline & $\mathrm{N}$ & 2397 & 2395 & 2397 & 2395 \\
\hline
\end{tabular}

All regressions include 24 cohort dummies, 47 state-of-birth dummies, region-of-birth * cohort interactions, region-of-residence dummies and an intercept. All regressions are weighted by the number of observations in the original cell. Standard errors (in parenthesis) are robust.

* significant at $10 \% * *$ significant at $5 \%$. 
TABLE 7: IS THE EFFECT OF EDUCATION ONLY THROUGH INCOME OR OCCUPATION?

Dependent Variable: 10-year death rate

\begin{tabular}{lll}
\hline Method & 2SLS & Mixed-2SLS \\
\hline
\end{tabular}

Education only (from table 4)

Education

$\begin{array}{cc}-0.045^{*} & -0.059 * * \\ (0.026) & (0.027)\end{array}$

$(0.026) \quad(0.027)$

Education and income

Education

$$
-0.046^{*} \quad-0.051 * *
$$

$(0.027) \quad(0.023)$

Family Income

$-1.00 \mathrm{e}-06^{* *} \quad-9.79 \mathrm{e}-07 * *$

$2.32 \mathrm{e}-07 \quad 2.33 \mathrm{e}-07$

Education, Income and occupation dummies

Education

$\begin{array}{cc}-0.036 & -0.042 \\ (0.029) & (0.029) \\ -8.4 \mathrm{e}-07 * * & -8.6 \mathrm{e}-07^{* *} \\ (2.3 \mathrm{e}-07) & (2.3 \mathrm{e}-07)\end{array}$

Occupations $(*)$

Professional

$-0.358 * * \quad-0.242 * *$

$(0.060) \quad(0.116)$

Managers

$-0.034 \quad-0.099$

$(0.107) \quad(0.073)$

Clerks

$0.004 \quad 0.090$

Sales

$(0.064) \quad(0.059)$
$-0.151)$

$-0.151 \quad-0.182 * *$

(0.099) (0.091)

Operatives

$-0.278 * * \quad-0.294 * *$

Service

$(0.069) \quad(0.072)$

$\begin{array}{ll}-0.006 & -0.065\end{array}$

$(0.054) \quad(0.069)$

Household services

$0.111 \quad 0.074$

$(0.073) \quad(0.067)$
$0.034)$

Farmer and farm laborers

$0.034 \quad 0.041$

$(0.085) \quad(0.075)$

All regressions include controls for all variables included in previous estimations (see Table 4). All regressions are weighted by the number of observations in the original cell. Standard errors (in parenthesis) are clustered at the state-of-birth and cohort level. Estimated using census data aggregated at the gender/state-of-birth/cohort level. $\mathrm{N}=4792$

Note: Total Family income: Mean 16647.16, S.E. 14280. (*)Occupation not available is the left-out category 